\title{
Review \\ Disrupted Calcium Homeostasis in Duchenne Muscular Dystrophy: A Common Mechanism behind Diverse Consequences
}

\author{
Barbara Zabłocka ${ }^{1}$ (D), Dariusz C. Górecki ${ }^{2,3, *}$ and Krzysztof Zabłocki ${ }^{4, *}$ \\ 1 Molecular Biology Unit, Mossakowski Medical Research Institute Polish Academy of Sciences, \\ 02-106 Warsaw, Poland; bzablocka@imdik.pan.pl \\ 2 School of Pharmacy and Biomedical Sciences, University of Portsmouth, St Michael's Building, \\ White Swan Road, Portsmouth PO1 2DT, UK \\ 3 Military Institute of Hygiene and Epidemiology, 01-163 Warsaw, Poland \\ 4 Laboratory of Cellular Metabolism, Nencki Institute of Experimental Biology Polish Academy of Sciences, \\ 02-093 Warsaw, Poland \\ * Correspondence: darek.gorecki@port.ac.uk (D.C.G.); k.zablocki@nencki.edu.pl (K.Z.)
}

check for updates

Citation: Zabłocka, B.; Górecki, D.C.; Zabłocki, K. Disrupted Calcium Homeostasis in Duchenne Muscular Dystrophy: A Common Mechanism behind Diverse Consequences. Int. J. Mol. Sci. 2021, 22, 11040. https:// doi.org/10.3390/ijms222011040

Academic Editor: Jose Javier Lopez

Received: 12 September 2021

Accepted: 9 October 2021

Published: 13 October 2021

Publisher's Note: MDPI stays neutral with regard to jurisdictional claims in published maps and institutional affiliations.

Copyright: (c) 2021 by the authors. Licensee MDPI, Basel, Switzerland. This article is an open access article distributed under the terms and conditions of the Creative Commons Attribution (CC BY) license (https:/ / creativecommons.org/licenses/by/ $4.0 /)$.

\begin{abstract}
Duchenne muscular dystrophy (DMD) leads to disability and death in young men. This disease is caused by mutations in the DMD gene encoding diverse isoforms of dystrophin. Loss of full-length dystrophins is both necessary and sufficient for causing degeneration and wasting of striated muscles, neuropsychological impairment, and bone deformities. Among this spectrum of defects, abnormalities of calcium homeostasis are the common dystrophic feature. Given the fundamental role of $\mathrm{Ca}^{2+}$ in all cells, this biochemical alteration might be underlying all the DMD abnormalities. However, its mechanism is not completely understood. While abnormally elevated resting cytosolic $\mathrm{Ca}^{2+}$ concentration is found in all dystrophic cells, the aberrant mechanisms leading to that outcome have cell-specific components. We probe the diverse aspects of calcium response in various affected tissues. In skeletal muscles, cardiomyocytes, and neurons, dystrophin appears to serve as a scaffold for proteins engaged in calcium homeostasis, while its interactions with actin cytoskeleton influence endoplasmic reticulum organisation and motility. However, in myoblasts, lymphocytes, endotheliocytes, and mesenchymal and myogenic cells, calcium abnormalities cannot be clearly attributed to the loss of interaction between dystrophin and the calcium toolbox proteins. Nevertheless, DMD gene mutations in these cells lead to significant defects and the calcium anomalies are a symptom of the early developmental phase of this pathology. As the impaired calcium homeostasis appears to underpin multiple DMD abnormalities, understanding this alteration may lead to the development of new therapies. In fact, it appears possible to mitigate the impact of the abnormal calcium homeostasis and the dystrophic phenotype in the total absence of dystrophin. This opens new treatment avenues for this incurable disease.
\end{abstract}

Keywords: Duchenne muscular dystrophy; calcium signalling; calcium homeostasis; mitochondria; endoplasmic reticulum

\section{Introduction}

Duchenne muscular dystrophy (DMD) is a debilitating and lethal neuromuscular disorder. Diagnosis is made usually between the ages of two and five. The earliest symptoms include waddling gate, frequent falling, and difficulties with climbing stairs. However, studies of human foetuses [1-3] and in various animal models [4-6] revealed that pathology starts already in the prenatal development. The first DMD defects are detectable in developing mesenchymal cells, before their differentiation into muscle [7]. Subsequently, muscle transcriptomes from asymptomatic DMD patients reveal typical dystrophic abnormalities [8], and developmental delays are present in 2-month-old DMD babies [9]. 
Progressing skeletal muscle weakness and wasting eventually lead to the loss of ambulation (around the age of 10-12) and to the respiratory impairment, the latter exacerbated by frequent infections. Patients require ventilation at around the age of 20. Cardiac muscle complications are usually the late symptom [4], suggesting that dystrophic striated muscle wasting may not be directly related to its workload. Eventually, the respiratory and/or cardiac failure develop, leading to the premature death between 20 and 40 years of age [10]. This range reflects the differences in the supportive care available to different patients' populations rather than the advances in the disease modifying therapies.

Although fatal consequences of DMD result from muscle damage, DMD also affects other organs and tissues. The most important are CNS and bone defects, the first leading to cognitive and behavioural impairments, the latter causing skeletal deformities exacerbating muscle symptoms.

\subsection{Genetics of Duchenne Muscular Dystrophy}

$\mathrm{DMD}$ is caused by the out-of-frame mutations within the $D M D$ gene. As the gene locus is on the X chromosome, DMD sufferers are mainly boys, with an incidence of 1 per 5000 male births, but 1 in 50 million females are also affected [11]. DMD is the largest human gene known, spanning $2.22 \mathrm{Mb}$ in the Xp21 region. It consists of 79 exons, and it is driven by eight promoters. Of the identified DMD mutations, $\sim 70 \%$ are exonic deletions, $<15 \%$ duplications, and $18-20 \%$ are small mutations, with $75 \%$ being the nonsense/frameshift types, with splice-site mutations constituting $20 \%$ [12]. One-third of all these are de novo mutations, which precludes the standard prenatal diagnosis from preventing the occurrence of the disease [13].

Importantly, there is an allelic variant of the disease, a mild form known as Becker muscular dystrophy (BMD), with an incidence between 1 in 18,000 and 1 in 30,000 live male births. The clinical picture of BMD is similar to DMD, yet symptoms begin later and progress at a much slower rate. The differences in clinical phenotypes, despite mutations affecting the same gene, appear to be caused by the mutation type: The loss-of-frame mutations resulting in the complete absence of dystrophin cause DMD, while mutations preserving the reading frame and thus allowing for the production of partially functional mini-dystrophin proteins result in BMD [14].

Transcription of human dystrophin may be initiated at eights promoters. Three of these drive the expression of the "full-length" dystrophin transcripts, translated into $427 \mathrm{kDa}$ dystrophin proteins. These differ at their $\mathrm{N}$-termini by only 3,7 , and 11 amino acids, but are expressed in a tissue-specific manner. The remaining five promoters are positioned across the gene and control expression of N-terminally truncated dystrophins (Dp412, Dp260, Dp140, Dp116 and Dp71) [15].

Of note, the genotype-phenotype correlation is not unambiguous [12,16]. The $D M D$ gene mutation hotspots are located in the regions affecting the full-length isoforms. Indeed, mutations leading to the loss of full-length $427 \mathrm{kDa}$ dystrophin are both necessary and sufficient for causing the muscle pathology $[17,18]$. The CNS abnormalities seem to be further exacerbated by the loss of the short isoforms Dp71 and Dp140, which are highly expressed in the normal brain [19]. There are few data on the muscle impact of mutations affecting these short isoforms or on the dystrophin-null patients. In this review, we have therefore focussed primarily on the canonical DMD caused by the absence of Dp427. Interestingly, genotype-phenotype correlation studies identified genetic modifiers [20], which can influence the disease progression in patients with the same DMD gene mutation e (see below).

\subsection{Dystrophin Structure and Presumed Functions}

The full-length dystrophin in striated muscle is located under the sarcolemma. It contains several domains with specific functions: Its $\mathrm{N}$-terminus interacts with actin cytoskeleton while the C-term contains domains which bind a set of dystrophin-associated proteins assembling into the subsarcolemmal and transmembrane dystrophin-associated protein 
(DAP) complex. Thus, dystrophin connects the actin cytoskeleton to the DAP complex in the cell membrane and DAPs, in turn, act as receptors for specific extracellular matrix proteins. Moreover, additional binding sites across the large rod domain allow interactions with further scaffolding and signalling proteins (reviewed in [21]). Particularly relevant to this overview are the direct and indirect interactions with proteins involved in calcium homeostasis such as plasma membrane calcium ATPase (PMCA), calcium channels TRPC1 and TRPC4, calmodulin, and calcineurin. These arrangements have been described based mostly on the muscle studies [22], but they exist in other cells too. Importantly, the composition of the DAP complex, and perhaps also its functions, can vary in different tissues and cells and even in different regions of the cell. These differences, where relevant to the topic of this review, will be discussed in detail.

Importantly, the mechanism(s) triggering muscle death have not been fully elucidated, although "the sarcolemmal hypothesis" put forward in 1990s has become the leading one and it weighs heavily on the therapeutic approaches. It stems from the findings on the dystrophin-DAP interactome abnormalities and can explain many clinical findings. This dominant view on the pathogenesis of DMD states that in the absence of dystrophin anchoring the DAP, this complex is not properly attached in the myofiber sarcolemma and that its loss destabilises the cell membrane, which becomes torn during contractions. Moreover, impaired architecture of intracellular scaffolds affects the appropriate localisation and function of various other proteins important for myofiber operations [23].

Yet, several studies, rather unexpectedly, challenged this widely accepted view of dystrophin anchoring DAP in the myofibre sarcolemma being a key to muscle health. It has been shown that ablation of dystrophin in fully differentiated myofibres did not trigger DAP dysregulation or muscle degeneration [24], while ablation of both dystrophin and DAP only triggered a mild decrease in muscle contractile force but not muscle degeneration [25]. Astoundingly, there is even evidence that myofibres can function entirely without dystrophin, just with overexpression of specific genetic modifiers [26]. Furthermore, cellautonomous defects are noticeable in DMD cells, which, when healthy, express the $14 \mathrm{~kb}$ DMD transcript but do not produce detectable levels of full-length dystrophins [27-30]. These, undoubtedly surprising findings, shed a new light on DMD pathophysiology (see below).

It is also important to remember that dystrophin deficiency leads to a variety of cell-specific symptoms, which are the sum of the loss of functions conveyed by specific isoforms in a cell-specific context. This variability may, at least partially, reflect the unique subcellular localisations of dystrophins in different cell types: in muscle fibres, dystrophin is evenly distributed beneath the sarcolemma, while in neurons it forms puncta limited to the postsynaptic regions [31-35].

Given this complex picture, it is remarkable that mutations affecting a range of dystrophins and occurring in different cells can still produce common abnormalities. In particular, in all dystrophic cells, whether in patients or animal models and whether muscle or non-muscle, one pathomechanism appears to be always present: the DMD-evoked changes in calcium homeostasis.

The characteristic feature of DMD is that tissues and organs of dystrophic individuals have exceedingly high cytosolic calcium ion concentrations, both upon stimulation as well as in resting conditions. This omnipresent feature of DMD pathology has been identified long before the genetic basis has been discovered and observed not only in patients but also in as distinct models of this disease as $m d x$ mouse and zebrafish and also in isolated dystrophic cells [36-39]. Moreover, altered calcium homeostasis is found in dystrophic cells which, when healthy, produce Dp427 but also in those that express transcripts encoding it but do not have detectable levels of dystrophin protein, which loss could explain the abnormalities. 


\section{Objectives of This Review}

Understanding the disrupted calcium homeostasis, the consistent alteration amongst the plethora of defects in this complex pathology, is important. It might be the one defect underlying all the other.

The purpose of this review is to (i) discuss the diverse aspects of calcium abnormalities across the affected tissues, as the aberrant mechanisms leading to it have cell-specific components, (ii) compare the obvious but overlooked disconnect between pathological mechanisms in cells where dystrophin can be a scaffold for proteins engaged in calcium homeostasis with cells in which calcium alterations cannot be clearly attributed to the loss of interaction between dystrophin and the calcium toolkit, and (iii) evaluate the existing therapeutic approaches for their impact on correcting the calcium overload in dystrophic cells.

We describe the current knowledge but also highlight the clear inconsistencies in our understanding of this dystrophic anomaly. Recognising these discrepancies is critically important for understanding past failures and developing new, better therapies.

\section{Mechanisms of Calcium Homeostasis}

Calcium ions play a universal and versatile role in all cells and, in fact, it would be difficult to find a completely calcium-independent cellular process [40]. Quiescent, healthy cells, electrically excitable as well as non-excitable ones, maintain the bulk cytosolic calcium ions concentration $\left(\left[\mathrm{Ca}^{2+}\right] \mathrm{c}\right)$ at the level of $100-120 \mathrm{nM}$, while extracellular $\left[\mathrm{Ca}^{2+}\right]$ level is approximately 1.0-1.8 $\mathrm{mM}$ [41-43].

Therefore, calcium fluxes through the plasma membrane and between organelles, as well as calcium storage within specific intracellular structures, must be precisely regulated and adjusted to specific demands of a particular cell and to its physiological state. General mechanisms are common for all metazoan cells, both electrically excitable and non-excitable ones and involve a relatively limited spectrum of molecules known as the calcium toolkit (Figure 1). It contains proteins responsible for activation of calcium signals (receptors, $\mathrm{Ca}^{2+}$ channels in the plasma membrane (PM), the endoplasmic reticulum (ER), acidic calcium stores (for review see in [44]) and proteins which transmit calcium signals between organelles participating in calcium responses, such as ER and PM, calcium sensing effectors, which execute cellular response indirectly (i.e., calmodulin, annexins, S-100 proteins) or directly (i.e., enzymes such as calcineurin, PKC, calpains, phospholipase A, MLCK, and many others), and finally proteins, which terminate calcium responses restoring the resting cytosolic concentration.
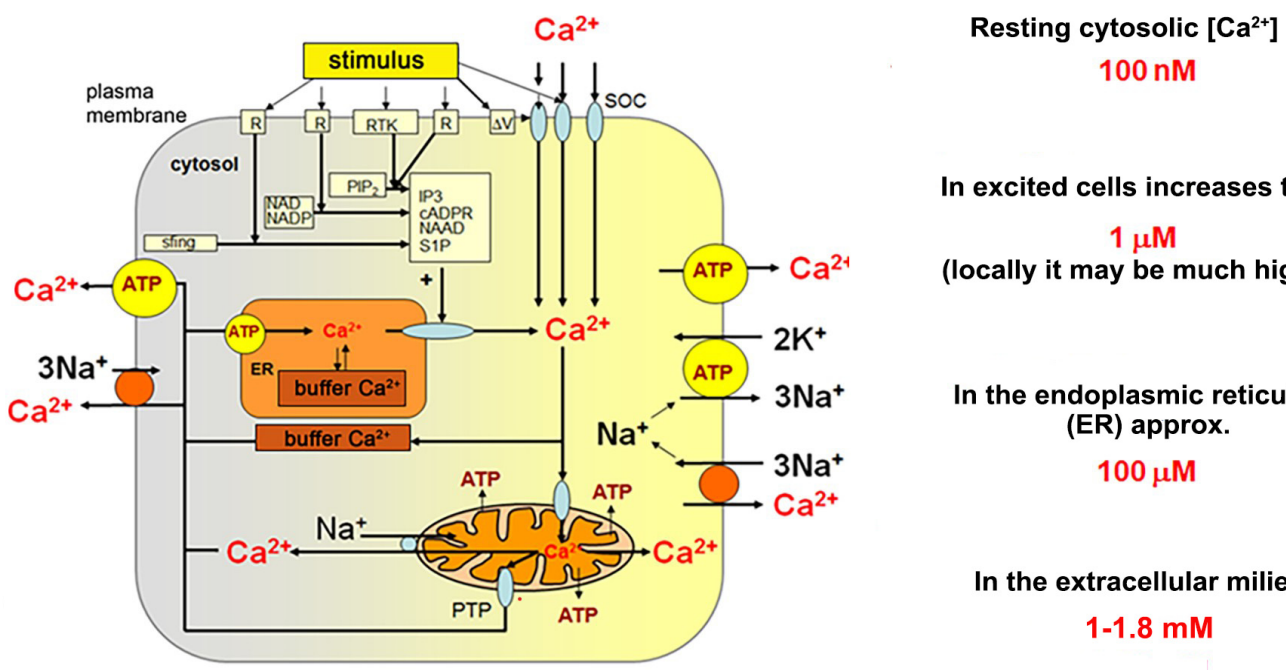

In excited cells increases to

$1 \mu \mathrm{M}$

(locally it may be much higher)
In the endoplasmic reticulum (ER) approx.
$100 \mu \mathrm{M}$

In the extracellular milieu

1-1.8 mM

Figure 1. Key elements of cellular calcium homeostasis in an animal cell. (According to Berridge et al. (2000) [40] Modified). 


\section{Calcium Signalling Toolkit}

$\mathrm{Ca}^{2+}$ entry requires activation of a variety of cell-specific calcium channels including voltage-gated, ligand-gated, stretch-activated, receptor-activated, and capacitative (storeoperated calcium entry (SOCE)). The latter is preceded by a depletion of the ER stores of calcium and engages Stim proteins in the ER membrane and Orai (and/or TRP-family member) proteins located in PM. $\mathrm{Ca}^{2+}$ release from ER occurs through ryanodine receptors (RyRs) or IP3-activated receptors located in the ER membrane. Both channels are also regulated by $\mathrm{Ca}^{2+}$. Generation of IP3 follows activation of specific receptors in PM and activation of PLC with participation of a specific $G$ protein. Mitochondria may transiently accumulate $\mathrm{Ca}^{2+}$, but only if the local $\mathrm{Ca}^{2+}$ concentration is substantially increased (i.e., in a close vicinity of calcium channels in the PM or ER membranes). ER contains $\mathrm{Ca}^{2+}$ binding proteins of high capacity and low affinity (calsequestrin and calreticulin). It is the major $\mathrm{Ca}^{2+}$ store in animal cells. $\mathrm{Ca}^{2+}$ is removed from the cytosol to the extracellular fluid against its concentration gradient (exploiting PMCA and sodium/calcium exchangers (NCX)) and to the ER stores (with sarco/endoplasmic calcium ATPase (SERCA)).

Although general principles of cellular calcium homeostasis and the set of molecular tools which are engaged in $\mathrm{Ca}^{2+}$ transport, storage and decoding calcium signals are basically the same in all cells, spatial organisation, interactions, and regulation of activity differ among various cell types. Figure 2 shows, in a very schematic way, specific arrangement of proteins which interact upon excitation of skeletal muscle.

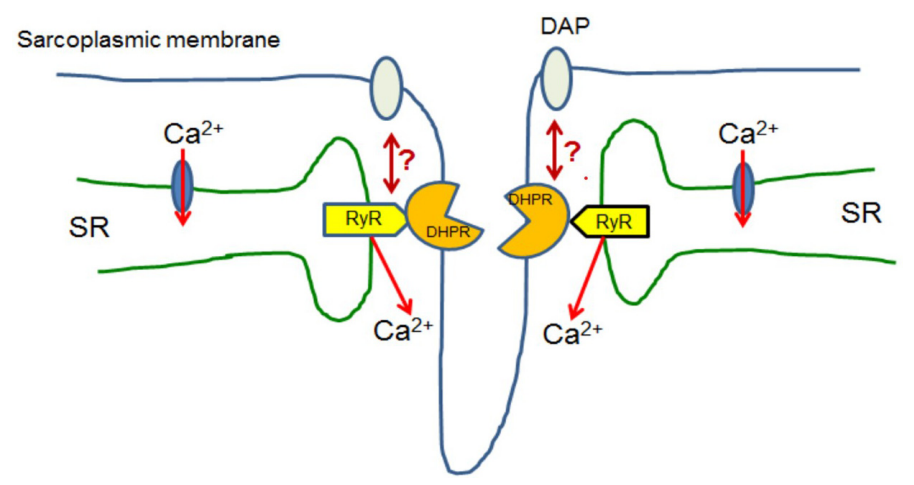

Figure 2. Skeletal muscle. Upon excitation, skeletal myofibres L-type calcium channel (DHPR/LTCC) proteins localised in selected regions of the sarcoplasmic membrane interact with ryanodine receptors $(\mathrm{RyR})$ localised in the specific regions of the sarcoplasmic reticulum (SR). Such structures are known as triads. $\mathrm{Ca}^{2+}$ released by these RyRs activates muscle contraction and then is transported back to SR. Presumably, dystrophin associated complex indirectly interacts with this mechanism, but its role is still unclear [45].

Calcium signals are triggered upon opening of $\mathrm{Ca}^{2+}$ channels in the plasma membrane, which allows $\mathrm{Ca}^{2+}$ entry, or due to activation of specific receptors in the ER membranes resulting in calcium release from these stores. In both cases, $\mathrm{Ca}^{2+}$ flux is driven by the electrochemical potential of this cation. These processes are very fast and do not need any additional energy input. In contrast, a restoration of the resting, post-stimulatory cytosolic $\mathrm{Ca}^{2+}$ concentration is an energy-consuming process. The latter relies on $\mathrm{Ca}^{2+}$ removal through the plasma membrane and/or its accumulation within the endoplasmic reticulum. In ER, calcium is bound and buffered by specific, low affinity and high capacity $\mathrm{Ca}^{2+}$ binding proteins (i.e., calsequestrin and calreticulin) and stored in an easily available form (Figure 1). $\mathrm{Ca}^{2+}$ removal from the cytosol to the extracellular space and to ER occurs against its concentration gradient, thus it needs energy delivered by ATP hydrolysis (for calcium pumps) or at the expense of the electrochemical potential of another ion simultaneously transported in the opposite direction (i.e., using sodium/calcium exchangers, NCX). Cytosolic calcium binding proteins (i.e., parvalbumin in skeletal muscle) and mitochondria, which may transiently accumulate $\mathrm{Ca}^{2+}$, modulate the intensity of calcium transients by 
locally buffering excess of $\mathrm{Ca}^{2+}$ ions and influencing calcium-dependent processes (such as $\mathrm{Ca}^{2+}$ release/uptake from/into ER or the store-operated calcium entry). Moreover, mitochondria are the major source of cellular ATP, which is required to cover energy demands of calcium pumps and ion exchangers.

Highly dynamic calcium homeostasis is maintained due to an orchestrated interplay between proteins composing the calcium toolkit. As their relative amounts, intracellular distribution as well as some regulatory and kinetic properties may differ in various cells, the final profiles of calcium responses (duration, amplitude, and frequency of calcium waves and oscillations) are not the same and undergo precise, cell-specific modulations. On the other hand, under the resting condition, cytosolic $\mathrm{Ca}^{2+}$ levels are basically similar in all cells. However, a highly ordered network of mutual interactions involving positive and negative feedback mechanisms responding to the actual local $\mathrm{Ca}^{2+}$ concentration within a particular cellular compartment seriously impedes attempts at identification of the primary consequence of changes in a protein, which does not belong to the calcium toolkit. Yet, such a protein not directly engaged in the cellular calcium handling may still seriously influence $\mathrm{Ca}^{2+}$ homeostasis. Dystrophin, as it will be explained, seems to be such a protein.

\section{Abnormal Calcium Homeostasis in DMD}

Loss of the $D M D$ gene expression appears to disturb the normal cytosolic $\mathrm{Ca}^{2+}$ level, which reflect the dynamic equilibrium between $\mathrm{Ca}^{2+}$ entry into and its removal from the cytosol. This physiological balance appears altered in all DMD affected cells.

Persistently elevated resting cytosolic $\mathrm{Ca}^{2+}$ concentrations and abnormally high calcium transients reflect an aberrant intracellular calcium homeostasis and are a direct cause of severe cellular damage and organ dysfunctions. First, they evoke mitochondrial calcium overload, altered cellular energy metabolism and activation of calcium-dependent enzymes, including PLA2 and calpains. These enzymes catalyse hydrolytic degradation of phospholipids and proteins, respectively [46,47]. Eventually, calcium overload may result in an activation of apoptosis and/or other modes of cell death $[48,49]$. Such pathological scenarios have indeed been found to occur in most of the dystrophic cells. Therefore, DMD defect may be considered as a generalised cellular calcium deregulation, where phenotypic consequences of altered calcium depend on individual, tissue-specific factors.

\section{Calcium Dysregulation in DMD Skeletal Muscle}

As the progressive muscle impairment is the cause of premature death of DMD patients, most studies have been focused on this tissue and relate to differentiated skeletal muscle fibres.

Myofibres have a unique mechanism responsible for large and reproducible increases in the cytosolic calcium concentration, which are crucial for muscle contraction. The electrical or chemical excitation of myofibres depolarises the sarcoplasmic membrane and, in consequence, triggers an interaction of the L-type voltage gated calcium channel/dihydropyridine receptor (LTCC/DHPR) located in the so-called T-tubules formed by sarcoplasmic membranes with the ryanodine receptors (RyR) in the SR membrane (Figure 2). This assembly of membranes is known as a triad [50]. Subsequently, $\mathrm{Ca}^{2+}$ is released from SR to the cytoplasm and activates muscle contraction. Skeletal muscle fibres may contract for a long time in a $\mathrm{Ca}^{2+}$-free environment due to the recycling of $\mathrm{Ca}^{2+}$ released from the SR stores upon cell excitation. It has been found that lack of dystrophin affects LTCC/DHPR-RyR interaction in skeletal muscle upon their stimulation [51,52].

\section{Dystrophin, the Scaffold}

The functional or structural link between dystrophin and specific proteins more or less directly involved in calcium signalling has been suggested quite early, but a precise mechanism of such interactions has remained unknown [30,43,53-57].

The earliest theory explaining calcium overload in dystrophic muscle fibres had implicated destabilisation and rupture of the sarcolemma in the wake of muscle contraction. 
Indeed, the leaking out of intracellular creatine kinase and uptake of Evans blue dye into damaged fibres and sarcolemmal "tears" (the so-called 'delta' lesions) described in early electron microscopy studies of dystrophic muscles [58,59] seem to support such a mechanism. However, while these findings certainly indicate severe damage of the sarcolemma of dystrophic pre-necrotic fibres, they are not evidence of its causation [60]. Therefore, while still recalled, this concept has been supplanted by other hypotheses.

Functions of the DAP complex in muscle are not limited to the mechanical strengthening and stabilisation of the sarcolemma. DAP is a multiprotein molecular scaffold, also for proteins, which belong to the calcium toolkit and are directly involved in the activation, modulation, or termination of calcium signals [61,62]. A significant proportion of almost 200 proteins found to be altered in the sarcolemma of $m d x-4 c v$ dystrophic mice (lacking the full-length dystrophin) were proteins involved in the regulation of ion homeostasis [63]. The DAP misassembly appears to affect calcium signalling at the sarcoplasmic membrane level [63].

While calcium channel blockers have little impact on the DMD pathology [64], the mechanisms downstream from the channel entry seem to affect the calcium response that directly controls the excitation-contraction coupling. Whereas expression of minidystrophin in $m d x$ muscle restored $\mathrm{Ca}^{2+}$ entry through channels [51], mass spec analysis of dystrophin and DAP in sarcoplasmic membrane compartments failed to confirm a direct interaction of dystrophin with the triad complex [45]. Therefore, alternatively, dystrophin and DAP may modulate the interaction between L-type $\mathrm{Ca}^{2+}$ channels and RyR $[51,65]$.

An excessive increase in cytosolic $\mathrm{Ca}^{2+}$ concentration in muscle cells during contraction and failure to return to the normal calcium level prevents muscle fibres from being able to relax. This deficit in muscle relaxation is a specific DMD feature across species 1 [66].

In myotubes differentiated from human induced pluripotent stem cells (hiPSCs) Shoji et al. (2015) showed that the electric stimulation-evoked contraction caused a pronounced calcium ion influx in DMD cells [67]. On the other hand, dystrophin re-expression corrected cytosolic $\mathrm{Ca}^{2+}$ concentration $[56,57]$ and prevented its efflux from SR through the inositoltrisphosphate receptor (IP3R) [43]. This observation indicates that, in dystrophic muscle cells, the excessive $\mathrm{Ca}^{2+}$ release via IP3R located in SR may cause its abnormal elevation in the cytosol and contribute to the imperfect muscle relaxation. Similarly, oxidative stress-related modifications of the RyR protein in dystrophic muscle result in the enhanced $\mathrm{Ca}^{2+}$ leakage from the SR stores, leading to permanently elevated cytosolic calcium levels [68]. In addition, an aberrant architecture and motility of ER due to lost interactions between dystrophin and actin, and thereby between actin cytoskeleton and the ER membranes, may influence the local cytosolic calcium concentration: $\mathrm{Ca}^{2+}$ is taken up or released by the neighbouring ER stores. Elevated $\mathrm{Ca}^{2+}$ release from ER is probably not the only cause of the prolongation of the post-excitatory phase of the calcium signal. A slowed down reuptake of $\mathrm{Ca}^{2+}$ due to decreased SERCA activity, observed in microsomes from dystrophic human muscles, extends this post-stimulatory elevation of cytosolic $\mathrm{Ca}^{2+}[69,70]$. On the other hand, slower $\mathrm{Ca}^{2+}$ release from SR and the altered SR organisation lead to dispersed $\mathrm{Ca}^{2+}$ puffs instead of those being localised at the triads [71]. Such a dysregulation of $\mathrm{Ca}^{2+}$ distribution within cells results in rises of $\mathrm{Ca}^{2+}$ in regions that are usually not exposed to such an excessive stimulation.

Abnormally high intracellular $\mathrm{Ca}^{2+}$ causes undesirable activation of hydrolytic enzymes [72] and this may result in irreversible damage [73].

\section{Calcium Abnormalities in DMD Myogenic and Non-Muscle Cells}

While the calcium-based regulation of skeletal muscle contraction is a unique phenomenon, muscle cells also use other, less tissue-specific mechanisms. These are shared with other cells, both electrically excitable and non-excitable. Cells essential for muscle regeneration and thus particularly important for the disease are myoblasts. Unlike myofibres, in these electrically non-excitable cells, release of $\mathrm{Ca}^{2+}$ from SR does not lead to 
contraction upon stimulation of LTCC/DHPR but other mechanisms of calcium signalling become activated instead.

\section{The Loss of the Absent}

Until recently, potential DMD abnormalities in myoblasts were not investigated. The reason for this was that healthy myoblasts do not express detectable dystrophin protein. Therefore, no abnormalities have been foreseen. Against this reasonable prediction, in proliferating myoblasts, mutations in the DMD gene cause multiple changes in calcium signalling $[28,30]$. Next-generation sequencing (NGS) and subsequent biochemical analyses revealed changes in the expression of a number of genes encoding calcium signalling and related proteins (e.g., STIM 1, SERCA1 and 2A, calsequestrin, PLC variants 3 and 4, NCX 1 and 2, PMCA, G $\alpha \mathrm{q} 11$, and $\mathrm{IP}_{3} \mathrm{R}$ ) [28]. Moreover, numerous functional abnormalities including elevated SOCE activity [30], altered responses of both metabotropic and ionotropic receptors [28,29], and reduced oxygen consumption, together with stimulated glycolysis [74] distinguish immortalised $m d x$ myoblasts from their wild type $(\mathrm{w} / \mathrm{t})$ equivalents. As these cells were maintained for generations in culture, changes appear to be cell-autonomous rather than triggered by the dystrophic niche. On the other hand, corresponding experiments in primary myoblasts confirmed key results obtained in immortalised cells $[30,75]$, thus excluding these alterations as being long-term culture effects. However, identification of the primary calcium response component directly affected in dystrophic myoblasts proved difficult so far, mainly because all elements of the "calcium puzzle" are interconnected and mutually dependent. Nevertheless, these findings complement the growing body of experimental data showing that biochemical consequences of $D M D$ gene mutations, including the aberrant calcium homeostasis, are detectable at the very early stages in muscle cell differentiation, and long before manifestation of any significant clinical symptoms.

In fact, in chimeras with incorporation of just $10-30 \%$ of $m d x$ embryonic stem cells (ESC), the heart and skeletal muscle displayed severe DMD phenotypes, with isolated cardiomyocytes showing increased calcium response [76]. Myogenic precursors obtained from DMD hIPSc exhibited the DMD phenotype upon differentiation towards the skeletal muscle lineage [7]. Furthermore, DMD lymphoblasts showed enhanced purinergic sensitivity [27] and dystrophic endotheliocytes are also dysfunctional [77-79].

These findings indicate that a phenotype can appear in a range of cells that, when healthy, are not known to express dystrophin proteins. Clearly, this poses an important question regarding the mechanism behind this alteration. All cells which present the phenotype express the full-length dystrophin transcript when healthy, and it is significantly depleted in dystrophic cells. Note that this $14 \mathrm{~kb}$ mRNA has a transcription time of $\sim 16 \mathrm{~h}$ [80]. Its expression in rapidly dividing myoblasts is therefore unlikely to be "illegitimate". Translation and a precise spatio-temporal requirement for small amounts of the full-length dystrophin, analogous to its role in satellite cells [81] or at neuronal synapses [34], require further studies. Another possibility is a mechanism not involving a protein product. Considering the increasing number of human pathologies caused by RNAmediated disease process, one could speculate that the loss of a large $14 \mathrm{~kb}$ transcript might trigger abnormalities [reviewed in [82]. Their presence in $m d x$ cells, that harbour a point mutation, indicate that the mechanism does not involve large gene rearrangements. In turn, improvements resulting from the expression of mini-dystrophins (see below) do not support toxic effects of its breakdown products. However, the impact of premature dystrophin transcript termination on the misregulation of other genes cannot be excluded [83].

Some recent data favour alterations of the epigenetic regulation as a more likely mechanism. Absence of dystrophin/DAPC in satellite cells leads to aberrant epigenetic control, which impairs functions of the "offspring" myoblasts that appear to be harbouring somatically heritable epigenetic changes [75].

It could be argued that restoration of selected functions with mini-dystrophin expression or via exon skipping contradicts the importance of $D M D$ gene expression in 
undifferentiated muscle cells. However, the mini-dystrophin transgene transfection and exon skipping in vivo are particularly effective in proliferating cells, such as myoblasts. Therefore, effects of these treatments might result from dystrophin re-expression in myoblasts with their subsequent differentiation into dystrophin-positive myotubes.

Taken together, these data show a continuum of DMD pathology that starts in development [7], affecting myogenic stem cells, persists in myoblasts and critically affects the functional development of differentiating myotubes [67]. As a result, dystrophic myofibres are unable to withstand the contraction-induced injury, while satellite cell and myoblast dysfunctions prevent normal regeneration, further exacerbating the pathology.

Importantly, data from other tissues further support the early, developmental nature of this pathology and confirm the key role of calcium alterations in the pathogenesis of DMD.

\section{Calcium Abnormalities in DMD Cardiac Muscle}

Although the regulatory mechanism of cardiomyocyte contraction differs from that in skeletal muscles, it also relies on changes in the cytosolic calcium concentration. The common feature of skeletal muscle and cardiac myocytes is high dystrophin abundance. However, its interaction with respective calcium toolkits is significantly different. In contrast to skeletal muscles, cardiomyocytes do not form triads and the heart muscle cannot contract in the absence of extracellular $\mathrm{Ca}^{2+} . \mathrm{Ca}^{2+}$ release from ER is based on the calciuminduced calcium release (CICR) mechanism. It involves activation of $\mathrm{RyR}$ by $\mathrm{Ca}^{2+}$ entering cells through voltage-gated channels rather than by a direct interaction of ER and PM in triads, as in the skeletal muscle. Therefore, in cardiomyocytes, the role of dystrophin in $\mathrm{Ca}^{2+}$ signalling may be different and indirect, or a non-structural role rather than a structural interaction cannot be excluded. Yet, the final outcome, i.e., the elevated $\mathrm{Ca}^{2+}$ concentration in the cytosol, is the same in both.

A reduced ability of $\mathrm{Ca}^{2+}$ removal from the cytosol to the SR/ER calcium stores caused by the significant reduction of SERCA activity is the most important anomaly in dystrophic cardiac cells. Inhibition of this calcium pump might be due to the increased amount of sarcolipin and a reduced proportion of phosphorylated phospholamban, which were detected in hearts of DMD patients and $m d x$ mice [84]. The dephosphorylated form of phospholamban inhibits SERCA, thus a ratio between phosphorylated and dephosphorylated protein is an important factor modulating SERCA activity. The reduced amount of calcium stored in SR/ER in dystrophic cardiomyocytes may also be in line with the observed increased calcium leak through RyR2 [85]. This may contribute to an aberrant profile of calcium transients: decreased calcium peak in systole and reduced $\mathrm{Ca}^{2+}$ reuptake in diastole, resulting in the reduced heart contractility in systole. Taken together, excess of calcium originates from intracellular stores because of hyperactivity of RyR2. It has also been suggested that abnormal $\mathrm{Ca}^{2+}$ entry into cells may be due to the altered kinetics of LTCC/DHPR voltage-gated channels leading to their delayed inactivation and therefore improper interaction with mitochondria and finally affected metabolic response] [86]. Moreover, it occurs via increased stretch-activated channels (SACs) activity or sarcolemma micro-tears $[54,56]$

The significance of membrane tears as a cause of elevated $\mathrm{Ca}^{2+}$ entry into dystrophic cells is uncertain, given its applicability just to the mechanically challenged cells. Tears are unlikely to occur in dystrophic neurons, yet these cells also show elevated calcium (see below). On the other hand, abnormal shear stress response could perhaps explain elevation of $\mathrm{Ca}^{2+}$ in dystrophic endothelial cells. As mentioned earlier, abnormalities in these cells are puzzling also because of the unclear molecular mechanism. Endothelial cells are not known to express full-length dystrophin and therefore should not be affected by the $m d x$ mutation. Yet, angiogenesis in these mice is seriously altered and impaired vascularisation affects regenerating muscles [87]. 


\section{Muscles That Get Away}

Whatever the mechanism, the importance of altered calcium homeostasis for the dystrophic pathology is further illustrated by the fact that DMD oculomotor muscles are spared, which coincides with these muscles not having increased intracellular calcium levels [88]. If extraocular muscles are indeed spared because they have a mechanism managing their calcium dysregulation, it might be possible to mitigate the impact of the altered calcium homeostasis in the absence of dystrophin and specific treatments augmenting such a mechanism could have a great therapeutic value in DMD. A further credibility to this notion is added by the results of fluoxetine treatment in dystrophic Sapje zebrafish [39]. In this study, fluoxetine completely reversed dystrophic muscle damage in the total absence of dystrophin, just by improving calcium homeostasis via calsequestrin levels.

So far, most of the research has been focused on skeletal, cardiac but also on the brain consequences of DMD, reflecting their significance for the morbidity and mortality of this disease and also because these tissues express detectable levels of Dp427 protein.

\section{Calcium Abnormalities in the Dystrophic CNS}

Neuropsychological abnormalities in DMD are clinically important. While all patients are affected, one-third of boys manifest with severe cognitive and behavioural defects. This more severe phenotype has been associated with the loss of short dystrophins, which are the most abundant brain isoforms. Yet, it must be stressed that neuropsychological abnormalities have been identified in the absence of Dp427 only, in both patients and $m d x$ mice. Furthermore, comparative proteomic profiling in $m d x-4 c v$ Dp427-deficient mouse brains revealed significant alterations in the $\mathrm{Ca}^{2+}$ binding protein calretinin and the $\mathrm{Ca}^{2+}$-pumping protein PMCA2, providing unbiased evidence that abnormalities of $\mathrm{Ca}^{2+}$ handling mechanisms occur in the absence of Dp427 [89]. These results confirm that the loss of full-length dystrophins is both necessary and sufficient to trigger calcium defects in various cells of the CNS, just as it is in skeletal and cardiac muscles.

Yet, in contrast to its uniform distribution under the sarcolemma of muscle fibres, $427 \mathrm{kDa}$ dystrophin in the brain is specifically located at the postsynaptic regions of the cortical, hippocampal and cerebral Purkinje neurons, as well as in glial end-feet $[34,35,90-94]$. Although the biochemical basis of $\mathrm{Ca}^{2+}$ signalling in the brain is the same as in other tissues, the phenotypic effects of dystrophy are specific. It is unsurprising, given the diversity of cells which express dystrophin in the CNS. For example, intracellular $\mathrm{Ca}^{2+}$ mishandling was found in $m d x$ cerebellar granule cells [95]. Moreover, elevation in $\left[\mathrm{Ca}^{2+}\right] c$ correlating with an increased $\mathrm{Ca}^{2+}$ release from intracellular stores, such as ER, was observed in pyramidal cortical and hippocampal neurons [42]. Electrophysiological data [96] showed an increased post-tetanic potentiation, which might also be linked to calcium-regulatory defects [97]. Therefore, dystrophin is currently believed to modulate synaptic terminal integrity, distinct forms of synaptic plasticity and regional cellular signal integration, while $\mathrm{Ca}^{2+}$ is a second messenger in information integration in neurons [98-101]. However, in contrast to the progressive pathology in muscle cells, the increased neuronal $\mathrm{Ca}^{2+}$ levels detected as early as at day 24, did not lead to neuronal cell loss even in 9-month-old $m d x$ mice [102]. $\mathrm{Ca}^{2+}$ dys-homeostasis also occurs in human DMD neurons [103], in line with alterations observed in skeletal and cardiac muscles [37,43,104]. Significant structural and molecular alterations were shown in neurons obtained by differentiation of hIPSc from a DMD patient affected by the cognitive impairment [103]. Moreover, DMD neurons showed a cytoplasmic $\mathrm{Ca}^{2+}$ overload associated with increased expression of the SERCA2 pump. Surprisingly, the decreased $\mathrm{Ca}^{2+}$ release peaks upon treatment of neurons with SERCA2 blocker (CPA) in $\mathrm{Ca}^{2+}$-free conditions, which indicates reduced levels of $\mathrm{Ca}^{2+}$ stored in ER. This result did not correlate with the increased expression of SERCA and could suggest that the intraluminal $\mathrm{Ca}^{2+}$ level in the dystrophic ER is lower than in the controls. This has, in fact, been reported in muscle [105]. 
Besides neurons, astrocytes generated from DMD hIPSc displayed defects in $\mathrm{Ca}^{2+}$ handling and a defective glutamate homeostasis [106].

Cognitive impairment in DMD has been associated with changes in the GABAergic system $[99,107,108]$. As GABA agonists can trigger a rise in $\left[\mathrm{Ca}^{2+}\right] \mathrm{c}$, which could be inhibited by ryanodine, it suggests that $\mathrm{Ca}^{2+}$ release from intracellular stores might be involved [109]. The consequence of altered GABA signalling may be the facilitation of NMDA receptor-dependent synaptic plasticity [96]. Altered functionality of GABAergic neurons may also be responsible, or at least contribute, to the GABA-mediated trophic effects during neuronal development [108].

More recently, specific alterations in the expression of glutamatergic and P2 $\times 7$ receptors were identified in the dystrophin-null mice cerebella [35], a finding consistent with the more severe CNS dysfunction occurring in patients with mutations affecting the short dystrophins.

Yet another causative factor in the cognitive impairment might be the dysregulation of the DAP complex, with associated aquaporin isoform 4 (AQP4) water and Kir 4.1 potassium channels, in perivascular glial end-feet. This is associated with a leaky blood-brain barrier (BBB) in dystrophic brains [110-112]. Given the importance of the intact BBB for the regulation of calcium concentrations between the extracellular and intracellular CNS compartments, the chronic $\mathrm{Ca}^{2+}$ overload in neurons and astrocytes, combined with impaired $\mathrm{BBB}$ buffering, may be intertwined with the defective synaptic transmission, resulting in the neurobehavioral impairment. Importantly, this dystrophic BBB abnormality is also caused by the absence of Dp427: in $m d x$ glia, Dp71, albeit reduced, was still present [112]. However, further loss of short dystrophins exacerbated BBB permeability, as found in $m d x^{\beta g e o}$ mice $[110,111]$.

\section{Dystrophic Mitochondria and Altered Calcium Homeostasis}

In all cell types, mitochondria are in the centre of calcium homeostasis. First, they produce cellular ATP, which is necessary to cover the energy demand of calcium transport against the concentration gradient $[46,113]$. Second, mitochondria transiently buffer an excess of cytosolic calcium, locally modifying its concentrations and thus influencing local calcium-dependent processes. Moreover, the elevation of $\mathrm{Ca}^{2+}$ concentration within physiological range stimulates mitochondrial energy metabolism and ADP phosphorylation. Thus, calcium homeostasis and mitochondrial energy metabolism are mutually dependent $[114,115]$. In resting cells, $\mathrm{Ca}^{2+}$ entry to the mitochondrial matrix is slow because of the low affinity of $\mathrm{Ca}^{2+}$ uniporter (MCU), while $\mathrm{Ca}^{2+}$ removal via mitochondrial $\mathrm{Na}^{+} / \mathrm{Ca}^{2+}$ exchanger (NCX) is relatively fast. This prevents mitochondrial $\mathrm{Ca}^{2+}$ accumulation. Therefore, in unstimulated cells, mitochondria do not play a role of calcium stores. However, upon excitation, when a local cytosolic $\mathrm{Ca}^{2+}$ concentration increases, mitochondria may transiently buffer an excess of this cation [113]. Conversely, an excessive $\mathrm{Ca}^{2+}$ uptake by mitochondria under pathological conditions of cellular calcium overload leads to an accelerated ROS generation, opening of the mitochondrial permeability transition pore (MPTP), activation of mitochondria-initiated apoptosis and collapse of the cellular energy metabolism $[47,116,117]$.

\subsection{Cardiac Mitochondria}

Interestingly, such disturbances, which are fatal for most cells, in cardiomyocytes might lead to a progressive adaptation of mitochondria, which increase their $\mathrm{Ca}^{2+}$ uptake ability [118]. The elevated mitochondrial $\mathrm{Ca}^{2+}$ accumulation that was observed in dystrophic cardiomyocytes may be considered as a compensatory effect, partially replacing reduced calcium storage capability in the SR/ER system. It has been suggested that more efficient mitochondrial calcium uptake in dystrophic cardiomyocytes may occur because of increased levels of the channel forming subunit of the mitochondrial calcium uniporter (MCU) [118]. Moreover, levels of the mitochondrial $\mathrm{Na}^{+} / \mathrm{Ca}^{2+}$ exchanger are also increased, thus mitochondrial $\mathrm{Ca}^{2+}$ clearance is stimulated. On the other hand, very high cytosolic 
$\mathrm{Ca}^{2+}$ concentration counteracts calcium extrusion via NCX. Mitochondria in dystrophic cardiomyocytes were speculated to be more resistant to $\mathrm{Ca}^{2+}$-induced damage because of a reduced tendency for opening the mitochondrial permeability transition pore (MPTP) [118] The MPTP opening due to excessive mitochondrial calcium levels enhances mitochondrial ROS production and depolarisation of the mitochondrial membrane, which are considered important in the cardiac pathology [119]. Interestingly, DMD-associated changes in cardiac mitochondria are noticeable before the clinical symptoms of this disease $[55,118]$.

\subsection{Skeletal Muscle Mitochondria}

In dystrophic skeletal muscle, mitochondrial MPTP seems to be more sensitive to $\mathrm{Ca}^{2+}$ and therefore prone to be opened with increased $\mathrm{Ca}^{2+}$ concentrations. While the amounts of protein components of the pore might be altered, these changes were not consistent [118] Moreover, the $\mathrm{Ca}^{2+}$ buffering capacity of dystrophic mitochondria was lower than in wild type muscles. Interestingly, a reduced MCU activity in isolated $m d x$ skeletal muscle mitochondria has been found [118], most likely due to the altered subunit composition of the MCU complex. Importantly, this stands in clear contrast to the aforementioned MCU increases in cardiomyocyte mitochondria [120]. Furthermore, in contrast to the cardiac data, mitochondria isolated from skeletal muscles did not show any changes in the NCX content.

\subsection{Structural Alterations}

Apart from the alterations in the amount and activity of mitochondrial calciumhandling proteins, aberrant intracellular architecture of mitochondrial networks and mitochondria-ER interactions have a huge impact on cellular calcium handling and its abnormalities in dystrophic cells. Mitochondria and the ER membranes form subcompartments known as mitochondrial associated membranes (MAMs), which contain specific calcium toolkit proteins and are crucial for the regulation of $\mathrm{Ca}^{2+}$ release from ER and for its mitochondrial uptake. These contact sites are directly engaged in the modulation of calcium signals and in the activation of mitochondrial energy metabolism. It was found that the density of MAMs in dystrophic cardiomyocytes is increased, while in skeletal muscles it is lower than in their wild type equivalents.

Aberrant organisation of the mitochondrial and ER networks may result from altered protein profiles at the mitochondria-ER junction and from modified cytoskeletal organisation due to lost interactions between dystrophin and actin filaments. It is plausible that pharmacological modulation of such intra-organelle contacts may be a target for DMD therapy. However, changes in the mitochondrial network architecture were also observed in $m d x$ myoblasts [74] as well as in cells derived from DMD patients [121,122], which complicates the picture.

\section{Impact of Therapies on Calcium Handling}

Normalisation of calcium handling in dystrophic muscles has long been tested as a potential therapeutic approach which could ameliorate DMD progression, and a number of drugs were tested. As many have been summarised in an excellent review [123] these examples will not be repeated here. However, several less-known pharmaceutical treatments illustrating the key points discussed in previous chapters will be considered.

The calcium channel blockers showed little impact on the DMD pathology [64], indicating that entry via these channels may only play a secondary role in this abnormality. However, there is evidence that other channel blockers can ameliorate the phenotype.

Among drugs which directly influence $\mathrm{Ca}^{2+}$ homeostasis those causing inhibition of $\mathrm{Ca}^{2+}$ channels in the sarcoplasmic membrane, stabilization of ryanodine receptors in SR/ER, overexpression of SERCA and reduction of the opening probability of MPTP were found to be of significance [124,125]. In a recent study, treatment of $m d x$ mice with SERCA activator reduced cytosolic $\mathrm{Ca}^{2+}$ levels, restored mitochondrial function, enhanced muscular strength, reduced muscular degeneration and fibrosis. Importantly, 
this treatment prevented exercise-induced muscular damage in the absence of dystrophin (doi:10.1093/hmg/ddab100).

Metformin treatment normalised MAMs and modulated mitochondrial metabolism in $m d x$ cardiac cells [126]. Although a beneficial effect of metformin on dystrophic cells needs further confirmation, its positive impact on a spectrum of metabolic processes is well established [127,128].

Deflazacort, which belongs to the class of glucocorticoids used in DMD therapy as antiinflammatory, is likely to influence SOCE and affect other calcium toolkit proteins. It was shown to enhance mitochondrial efficiency in $m d x$ skeletal muscle cells [129]. However, molecular mechanisms behind these effects and their possible impact on DMD progression are still elusive.

An interesting example of an approach aimed at the destabilisation and rupture of the dystrophic sarcolemma is the copolymer-based treatment. Application of these membrane-interacting synthetic molecules, known also as poloxamers or pluronics, to $m d x$ cardiomyocytes in vitro ameliorated the calcium overload. Moreover, in $m d x$ mice in vivo, P188 improved cardiac functions [130]. However, the same copolymer not only failed to prevent sarcolemma leakage in $m d x$ skeletal muscle but even had some deleterious effects on skeletal muscle functions $[131,132]$. These cardio-specific effects of pluronics may be explained by very significant differences in the physico-chemical properties of the sarcolemma in cardiac and skeletal muscles or that their mechanism of action is different than as a membrane sealant.

While there are still many questions regarding the pathomechanism(s) of DMD cognitive impairment, improvements resulting from dystrophin re-expression in $m d x$ brains [133] indicate that, even in adults, some correction could be achieved. Unfortunately, none of the currently tested approaches addresses this significant burden for DMD patients and their families.

In this respect, a pathological commonality between muscle and cognitive dysfunctions might be expedient. P2RX7 is one of the main drivers of both DMD muscle damage and inflammation [134], as well as the key mediator of inflammatory processes within the nervous system [135]. Therefore, P2RX7 appears to be such a common link. Indeed, ablation and pharmacological inhibition of this purinoceptor alleviated muscle symptoms $[136,137]$ and also improved recognition memory and diminished anxiogenic-like behaviours [138]. Importantly, the key effect of the activation of this ATP-gated ion channel permeable to divalent cations is the increase of intracellular calcium levels $[139,140]$. The P2RX7 blockade appears to be the first clinically applicable comprehensive treatment for DMD. It is also yet another example that therapies exploiting more accessible targets downstream from the absence of dystrophin offer a better chance of success [141]. In fact, the entire extracellular ATP-mediated signalling network might be such a target [28].

Gentamycin, later supplanted by the more specific Ataluren, initiate a read through premature termination codons and therefore synthesis of full-length dystrophin. In the dystrophic skeletal muscles, gentamycin improved the direct interaction between voltagegated channels and RyR, which occurs upon cell excitation. In $m d x$ smooth muscle, in which calcium signalling abnormalities are less severe than in skeletal muscle fibres, gentamycin treatment stimulated RyR expression and restored CICR-based activation of calcium signalling [142]. Exon skipping restores a reading frame and expression of truncated but functionally active mini-dystrophin [143]. Interestingly, exon-skipping produced very similar effects to those evoked by gentamycin [142]. Thus, therapeutic approaches leading to re-expression of the full length or mini-dystrophin both led to improved calcium homeostasis in muscle cells in the same experimental paradigm.

\section{Are There Calcium Abnormalities in BMD?}

As explained in the Introduction, BMD is a milder variant of muscular dystrophy caused by mutations that preserve the reading frame and result in truncated but semifunctional mini- or micro-dystrophins being expressed. The BDM progress, albeit slower 
than in the case of DMD, may also lead to disability and premature death. Surprisingly, we failed to identify in the literature any studies that directly addressed the effects of BMD mutations on the $\mathrm{Ca}^{2+}$ homeostasis. Some indirect data indicate that changes in calcium signalling in BMD cells should be less severe. For example, only limited impact of BMD on mitochondrial metabolism suggests that mitochondrial $\mathrm{Ca}^{2+}$ buffering capacity as well as ATP delivery are not affected [144]. Furthermore, reports that re-expression of mini-dystrophin, either through gene therapy or exon skipping, resulting in the conversion of DMD into BMD, have been shown to stabilise calcium homeostasis. Specifically: exon 45 skipping normalised $\mathrm{Ca}^{2+}$ signals in cardiomyocytes derived from IPSc [145]; Dystrophin re-expression via exon-skipping prevented the excessive $\mathrm{Ca}^{2+}$ load and myotube damage in golden retriever dogs [146] and in $m d x$ mice [142]. In yet another experiment, transfection of dystrophic muscle fibres with a mini-dystrophin-encoding gene prevented an abnormal $\mathrm{Ca}^{2+}$ efflux from SR through the inositol trisphosphate receptor (IP3R) [52]. Expression of mini-dystrophin in $m d x$ muscle restored the abnormal $\mathrm{Ca}^{2+}$ entry through channels [51]. Thus, expression of mini-dystrophins appears to ameliorate the dystrophic calcium overload, indicating that binding sites in the rod domain may be largely dispensable for maintaining calcium homeostasis.

\section{Concluding Remarks}

Although often attempted, DMD pathology cannot be currently explained by a single mechanism. It is likely that specific, often overlapping, sometimes distinct processes are at play in different tissues and at different stages of the disease. However, abnormalities of calcium homeostasis are the common pathological feature found in both DMD patients and all animal models of this disease and in all dystrophic cells, irrespective whether electrically excitable or non-excitable. Mutations affecting the full-length dystrophin expression are both necessary and sufficient for the calcium phenotype to occur, while the loss of short dystrophins may exacerbate it. However, the role of dystrophin in calcium signalling is not completely understood, which may explain why no treatment targeting calcium pathways has been successful so far.

In dystrophic cells, the net outcome is always the elevated resting cytosolic $\mathrm{Ca}^{2+}$ concentration, but the biochemical mechanisms leading to that outcome may have components specific to a particular cell type. The intensity of calcium responses in dystrophic cells results from the aberrant, stimulus-dependent interplay between proteins involved in maintaining calcium homeostasis, and these differ across cells.

In skeletal muscles, cardiomyocytes, and neurons, the DAP complex, properly assembled only in the presence of dystrophin, appears to serve as a scaffold for proteins engaged in calcium homeostasis, while dystrophin interactions with the actin cytoskeleton influence ER organisation and motility. However, in some cells, calcium abnormalities cannot be linked to the increased sensitivity to mechanical stimuli or even clearly attributed to the loss of interaction between dystrophin and the calcium toolbox proteins. For example, myoblasts, lymphocytes, and endotheliocytes, despite expressing dystrophin transcripts, are not known to synthesise detectable levels of Dp427 protein. Yet, DMD gene mutations lead, in these cells, to significant calcium abnormalities. In fact, already in the developing dystrophic stem cells (including ESC), in mesenchymal and myogenic cells, significant calcium anomalies are not only present but appear to contribute to the early pathology.

Given that the impairment of calcium homeostasis seems to underpin multiple DMD abnormalities in a plethora of dystrophic cells, understanding mechanisms behind this alteration may lead to the development of better therapeutic approaches to treat this devastating and incurable disease.

Author Contributions: Equal contribution of all authors in all aspects of manuscript preparation. Conceptualization, B.Z., D.C.G. and K.Z.; writing-original draft preparation, B.Z., D.C.G. and K.Z.; writing-review and editing, B.Z., D.C.G. and K.Z. All authors have read and agreed to the published version of the manuscript. 
Funding: Aspects of this work were supported by statutory MMRI (B.Z.), the Polish Ministry of National Defense project "Kościuszko" No.: 523/2017/DA. (D.C.G.), the National Science Centre, Poland, accordingly to the decision number DEC-2013/11/B/NZ3/01573 (K.Z.).

Institutional Review Board Statement: Not applicable.

Informed Consent Statement: Not applicable.

Data Availability Statement: Not applicable.

Conflicts of Interest: The authors declare no conflict of interest.

$\begin{array}{ll}\text { Abbreviations } & \\ \text { AQP4 } & \text { Aquaporin isoform 4 } \\ \text { BMD } & \text { Becker muscular dystrophy } \\ \text { DMD } & \text { Duchenne muscular dystrophy } \\ \text { DAP } & \text { dystrophin-associated proteins complex } \\ \text { ER/SR } & \text { endoplasmic reticulum/sarcoplasmic reticulum } \\ \text { SOCE } & \text { store-operated calcium entry } \\ \text { NCX } & \text { Na+/Ca }{ }^{2+} \text { exchanger } \\ \text { LTCC/DHPR } & \text { L-type calcium channel/dihydropiridine receptor } \\ \text { CICR } & \text { Calcium-induced calcium release } \\ \text { SERCA } & \text { sarco/endoplasmic calcium ATPase } \\ \text { PMCA } & \text { plasma membrane calcium ATPase } \\ \text { MCU } & \text { mitochondrial calcium uniporter } \\ \text { RyR } & \text { ryanodine receptor } \\ \text { MPTP } & \text { mitochondrial permeability transition pore }\end{array}$

\section{References}

1. Toop, J.; Emery, A.E. Muscle histology in fetuses at risk for Duchenne muscular dystrophy. Clin. Genet. 1974, 5, 230-233. [CrossRef]

2. Emery, A.E. Muscle histology and creatine kinase levels in the foetus in Duchenne muscular dystrophy. Nature 1977, $266,472-473$. [CrossRef]

3. Vassilopoulos, D.; Emery, A.E. Muscle nuclear changes in fetuses at risk for Duchenne muscular dystrophy. J. Med. Genet. 1977, 14, 13-15. [CrossRef]

4. Nguyen, F.; Cherel, Y.; Guigand, L.; Goubault-Leroux, I.; Wyers, M. Muscle lesions associated with dystrophin deficiency in neonatal golden retriever puppies. J. Comp. Pathol. 2002, 126, 100-108. [CrossRef]

5. Bassett, D.I.; Bryson-Richardson, R.J.; Daggett, D.F.; Gautier, P.; Keenan, D.G.; Currie, P.D. Dystrophin is required for the formation of stable muscle attachments in the zebrafish embryo. Development 2003, 130, 5851-5860. [CrossRef] [PubMed]

6. Merrick, D.; Stadler, L.K.; Larner, D.; Smith, J. Muscular dystrophy begins early in embryonic development deriving from stem cell loss and disrupted skeletal muscle formation. Dis. Models Mech. 2009, 2, 374-388. [CrossRef] [PubMed]

7. Mournetas, V.; Massouridès, E.; Dupont, J.B.; Kornobis, E.; Polvèche, H.; Jarrige, M.; Dorval, A.R.L.; Gosselin, M.R.F.; Manousopoulou, A.; Garbis, S.D.; et al. Myogenesis modelled by human pluripotent stem cells: A multi-omic study of Duchenne myopathy early onset. J. Cachexia Sarcopenia Muscle 2021, 12, 209-232. [CrossRef]

8. Pescatori, M.; Broccolini, A.; Minetti, C.; Bertini, E.; Bruno, C.; D’Amico, A.; Bernardini, C.; Mirabella, M.; Silvestri, G.; Giglio, V.; et al. Gene expression profiling in the early phases of DMD: A constant molecular signature characterizes DMD muscle from early postnatal life throughout disease progression. FASEB J. 2007, 21, 1210-1226. [CrossRef] [PubMed]

9. Van Dommelen, P.; van Dijk, O.; de Wilde, J.A.; Verkerk, P.H. Early developmental milestones in Duchenne muscular dystrophy. Dev. Med. Child Neurol. 2020, 62, 1198-1204. [CrossRef]

10. Koeks, Z.; Bladen, C.L.; Salgado, D.; van Zwet, E.; Pogoryelova, O.; McMacken, G.; Monges, S.; Foncuberta, M.E.; Kekou, K.; Kosma, K.; et al. Clinical Outcomes in Duchenne Muscular Dystrophy: A Study of 5345 Patients from the TREAT-NMD DMD Global Database. J. Neuromuscul. Dis. 2017, 4, 293-306. [CrossRef]

11. Crisafulli, S.; Sultana, J.; Fontana, A.; Salvo, F.; Messina, S.; Trifiro, G. Global epidemiology of Duchenne muscular dystrophy: An updated systematic review and meta-analysis. Orphanet. J. Rare Dis. 2020, 15, 141. [CrossRef] [PubMed]

12. Juan-Mateu, J.; Gonzalez-Quereda, L.; Rodriguez, M.J.; Baena, M.; Verdura, E.; Nascimento, A.; Ortez, C.; Baiget, M.; Gallano, P. DMD Mutations in 576 Dystrophinopathy Families: A Step Forward in Genotype-Phenotype Correlations. PLoS ONE 2015, 10, e0135189. [CrossRef]

13. Monaco, A.P.; Bertelson, C.J.; Liechti-Gallati, S.; Moser, H.; Kunkel, L.M. An explanation for the phenotypic differences between patients bearing partial deletions of the DMD locus. Genomics 1988, 2, 90-95. [CrossRef] 
14. Muntoni, F.; Torelli, S.; Ferlini, A. Dystrophin and mutations: One gene, several proteins, multiple phenotypes. Lancet Neurol. 2003, 2, 731-740. [CrossRef]

15. Duan, D.; Goemans, N.; Takeda, S.; Mercuri, E.; Aartsma-Rus, A. Duchenne muscular dystrophy. Nat. Rev. Dis. Primers 2021, 7, 13. [CrossRef] [PubMed]

16. Desguerre, I.; Christov, C.; Mayer, M.; Zeller, R.; Becane, H.M.; Bastuji-Garin, S.; Leturcq, F.; Chiron, C.; Chelly, J.; Gherardi, R.K. Clinical heterogeneity of duchenne muscular dystrophy (DMD): Definition of sub-phenotypes and predictive criteria by long-term follow-up. PLoS ONE 2009, 4, e4347. [CrossRef]

17. Masubuchi, N.; Shidoh, Y.; Kondo, S.; Takatoh, J.; Hanaoka, K. Subcellular localization of dystrophin isoforms in cardiomyocytes and phenotypic analysis of dystrophin-deficient mice reveal cardiac myopathy is predominantly caused by a deficiency in full-length dystrophin. Exp. Anim. 2013, 62, 211-217. [CrossRef]

18. Aartsma-Rus, A.; Ginjaar, I.B.; Bushby, K. The importance of genetic diagnosis for Duchenne muscular dystrophy. J. Med. Genet. 2016, 53, 145-151. [CrossRef]

19. Taylor, P.J.; Betts, G.A.; Maroulis, S.; Gilissen, C.; Pedersen, R.L.; Mowat, D.R.; Johnston, H.M.; Buckley, M.F. Dystrophin gene mutation location and the risk of cognitive impairment in Duchenne muscular dystrophy. PLoS ONE 2010, 5, e8803. [CrossRef]

20. Bello, L.; Pegoraro, E. The "Usual Suspects": Genes for Inflammation, Fibrosis, Regeneration, and Muscle Strength Modify Duchenne Muscular Dystrophy. J. Clin. Med. 2019, 8, 649. [CrossRef]

21. Zhao, J.; Kodippili, K.; Yue, Y.; Hakim, C.H.; Wasala, L.; Pan, X.; Zhang, K.; Yang, N.N.; Duan, D.; Lai, Y. Dystrophin contains multiple independent membrane-binding domains. Hum. Mol. Genet. 2016, 25, 3647-3653. [CrossRef] [PubMed]

22. Dalkilic, I.; Kunkel, L.M. Muscular dystrophies: Genes to pathogenesis. Curr. Opin. Genet. Dev. 2003, 13, 231-238. [CrossRef]

23. Gao, Q.Q.; McNally, E.M. The Dystrophin Complex: Structure, Function, and Implications for Therapy. Compr. Physiol. 2015, 5, 1223-1239. [CrossRef]

24. Ghahramani Seno, M.M.; Graham, I.R.; Athanasopoulos, T.; Trollet, C.; Pohlschmidt, M.; Crompton, M.R.; Dickson, G. RNAimediated knockdown of dystrophin expression in adult mice does not lead to overt muscular dystrophy pathology. Hum. Mol. Genet. 2008, 17, 2622-2632. [CrossRef]

25. Rader, E.P.; Turk, R.; Willer, T.; Beltrán, D.; Inamori, K.; Peterson, T.A.; Engle, J.; Prouty, S.; Matsumura, K.; Saito, F.; et al. Role of dystroglycan in limiting contraction-induced injury to the sarcomeric cytoskeleton of mature skeletal muscle. Proc. Natl. Acad. Sci. USA 2016, 113, 10992-10997. [CrossRef] [PubMed]

26. Vieira, N.M.; Elvers, I.; Alexander, M.S.; Moreira, Y.B.; Eran, A.; Gomes, J.P.; Marshall, J.L.; Karlsson, E.K.; Verjovski-Almeida, S.; Lindblad-Toh, K.; et al. Jagged 1 Rescues the Duchenne Muscular Dystrophy Phenotype. Cell 2015, 163, 1204-1213. [CrossRef]

27. Ferrari, D.; Munerati, M.; Melchiorri, L.; Hanau, S.; di Virgilio, F.; Baricordi, O.R. Responses to extracellular ATP of lymphoblastoid cell lines from Duchenne muscular dystrophy patients. Am. J. Physiol. 1994, 267, C886-C892. [CrossRef] [PubMed]

28. Rog, J.; Oksiejuk, A.; Gosselin, M.R.F.; Brutkowski, W.; Dymkowska, D.; Nowak, N.; Robson, S.; Gorecki, D.C.; Zablocki, K. Dystrophic mdx mouse myoblasts exhibit elevated ATP/UTP-evoked metabotropic purinergic responses and alterations in calcium signalling. Biochim. Biophys. Acta Mol. Basis Dis. 2019, 1865, 1138-1151. [CrossRef]

29. Yeung, D.; Zablocki, K.; Lien, C.F.; Jiang, T.; Arkle, S.; Brutkowski, W.; Brown, J.; Lochmuller, H.; Simon, J.; Barnard, E.A.; et al. Increased susceptibility to ATP via alteration of P2X receptor function in dystrophic mdx mouse muscle cells. FASEB J. 2006, 20, 610-620. [CrossRef]

30. Onopiuk, M.; Brutkowski, W.; Young, C.; Krasowska, E.; Rog, J.; Ritso, M.; Wojciechowska, S.; Arkle, S.; Zablocki, K.; Gorecki, D.C. Store-operated calcium entry contributes to abnormal $\mathrm{Ca}^{2+}$ signalling in dystrophic mdx mouse myoblasts. Arch. Biochem. Biophys. 2015, 569, 1-9. [CrossRef]

31. Blake, D.J.; Tinsley, J.M.; Davies, K.E. Utrophin: A structural and functional comparison to dystrophin. Brain Pathol. 1996, 6, 37-47. [CrossRef] [PubMed]

32. Huard, J.; Tremblay, J.P. Localization of dystrophin in the Purkinje cells of normal mice. Neurosci. Lett. 1992, 137, 105-108. [CrossRef]

33. Jancsik, V.; Hajos, F. Differential distribution of dystrophin in postsynaptic densities of spine synapses. Neuroreport 1998, 9 , 2249-2251. [CrossRef] [PubMed]

34. Lidov, H.G.; Byers, T.J.; Watkins, S.C.; Kunkel, L.M. Localization of dystrophin to postsynaptic regions of central nervous system cortical neurons. Nature 1990, 348, 725-728. [CrossRef] [PubMed]

35. Jackson, T.; Seifi, M.; Górecki, D.C.; Swinny, J.D. Specific Dystrophins Selectively Associate with Inhibitory and Excitatory Synapses of the Mouse Cerebellum and their Loss Alters Expression of P2X7 Purinoceptors and Pro-Inflammatory Mediators. Cell. Mol. Neurobiol. 2021. online ahead of print. [CrossRef]

36. Turner, P.R.; Fong, P.Y.; Denetclaw, W.F.; Steinhardt, R.A. Increased calcium influx in dystrophic muscle. J. Cell Biol. 1991, 115, 1701-1712. [CrossRef]

37. Turner, P.R.; Westwood, T.; Regen, C.M.; Steinhardt, R.A. Increased protein degradation results from elevated free calcium levels found in muscle from mdx mice. Nature 1988, 335, 735-738. [CrossRef]

38. Hopf, F.W.; Turner, P.R.; Denetclaw, W.F., Jr.; Reddy, P.; Steinhardt, R.A. A critical evaluation of resting intracellular free calcium regulation in dystrophic mdx muscle. Am. J. Physiol. 1996, 271, C1325-C1339. [CrossRef] [PubMed]

39. Waugh, T.A.; Horstick, E.; Hur, J.; Jackson, S.W.; Davidson, A.E.; Li, X.; Dowling, J.J. Fluoxetine prevents dystrophic changes in a zebrafish model of Duchenne muscular dystrophy. Hum. Mol. Genet. 2014, 23, 4651-4662. [CrossRef] 
40. Berridge, M.J.; Lipp, P.; Bootman, M.D. The versatility and universality of calcium signalling. Nat. Rev. Mol. Cell Biol. 2000, 1, 11-21. [CrossRef]

41. Lopez, J.R.; Alamo, L.; Caputo, C.; DiPolo, R.; Vergara, S. Determination of ionic calcium in frog skeletal muscle fibers. Biophys. J. 1983, 43, 1-4. [CrossRef]

42. Lopez, J.R.; Kolster, J.; Uryash, A.; Estève, E.; Altamirano, F.; Adams, J.A. Dysregulation of Intracellular Ca ${ }^{2+}$ in Dystrophic Cortical and Hippocampal Neurons. Mol. Neurobiol. 2018, 55, 603-618. [CrossRef]

43. Mijares, A.; Altamirano, F.; Kolster, J.; Adams, J.A.; Lopez, J.R. Age-dependent changes in diastolic $\mathrm{Ca}^{2+}$ and $\mathrm{Na}^{+}$concentrations in dystrophic cardiomyopathy: Role of $\mathrm{Ca}^{2+}$ entry and IP3. Biochem. Biophys. Res. Commun. 2014, 452, 1054-1059. [CrossRef]

44. Patel, S.; Docampo, R. Acidic calcium stores open for business: Expanding the potential for intracellular Ca ${ }^{2+}$ signaling. Trends Cell Biol. 2010, 20, 277-286. [CrossRef]

45. Murphy, S.; Ohlendieck, K. Mass spectrometric identification of dystrophin, the protein product of the Duchenne muscular dystrophy gene, in distinct muscle surface membranes. Int. J. Mol. Med. 2017, 40, 1078-1088. [CrossRef] [PubMed]

46. Gissel, H. The role of $\mathrm{Ca}^{2+}$ in muscle cell damage. Ann. N. Y. Acad. Sci. 2005, 1066, 166-180. [CrossRef] [PubMed]

47. Smith, M.A.; Schnellmann, R.G. Calpains, mitochondria, and apoptosis. Cardiovasc. Res. 2012, 96, 32-37. [CrossRef]

48. Vanlangenakker, N.; Vanden Berghe, T.; Krysko, D.V.; Festjens, N.; Vandenabeele, P. Molecular mechanisms and pathophysiology of necrotic cell death. Curr. Mol. Med. 2008, 8, 207-220. [CrossRef]

49. Farooqui, A.A.; Ong, W.Y.; Horrocks, L.A. Biochemical aspects of neurodegeneration in human brain: Involvement of neural membrane phospholipids and phospholipases A2. Neurochem. Res. 2004, 29, 1961-1977. [CrossRef] [PubMed]

50. Barone, V.; Randazzo, D.; Del Re, V.; Sorrentino, V.; Rossi, D. Organization of junctional sarcoplasmic reticulum proteins in skeletal muscle fibers. J. Muscle Res. Cell Motil. 2015, 36, 501-515. [CrossRef]

51. Friedrich, O.; Both, M.; Gillis, J.M.; Chamberlain, J.S.; Fink, R.H. Mini-dystrophin restores L-type calcium currents in skeletal muscle of transgenic mdx mice. J. Physiol. 2004, 555, 251-265. [CrossRef]

52. Balghi, H.; Sebille, S.; Mondin, L.; Cantereau, A.; Constantin, B.; Raymond, G.; Cognard, C. Mini-dystrophin expression downregulates IP3-mediated calcium release events in resting dystrophin-deficient muscle cells. J. Gen. Physiol. 2006, 128, $219-230$. [CrossRef]

53. Constantin, B.; Sebille, S.; Cognard, C. New insights in the regulation of calcium transfers by muscle dystrophin-based cytoskeleton: Implications in DMD. J. Muscle Res. Cell Motil. 2006, 27, 375-386. [CrossRef]

54. Allen, D.G.; Gervasio, O.L.; Yeung, E.W.; Whitehead, N.P. Calcium and the damage pathways in muscular dystrophy. Can. J. Physiol. Pharmacol. 2010, 88, 83-91. [CrossRef]

55. Ascah, A.; Khairallah, M.; Daussin, F.; Bourcier-Lucas, C.; Godin, R.; Allen, B.G.; Petrof, B.J.; Des Rosiers, C.; Burelle, Y. Stressinduced opening of the permeability transition pore in the dystrophin-deficient heart is attenuated by acute treatment with sildenafil. Am. J. Physiol. Heart Circ. Physiol. 2011, 300, H144-H153. [CrossRef] [PubMed]

56. Fanchaouy, M.; Polakova, E.; Jung, C.; Ogrodnik, J.; Shirokova, N.; Niggli, E. Pathways of abnormal stress-induced Ca ${ }^{2+}$ influx into dystrophic mdx cardiomyocytes. Cell Calcium 2009, 46, 114-121. [CrossRef] [PubMed]

57. Mehler, M.F. Brain dystrophin, neurogenetics and mental retardation. Brain Res. Brain Res. Rev. 2000, 32, 277-307. [CrossRef]

58. Mokri, B.; Engel, A.G. Duchenne dystrophy: Electron microscopic findings pointing to a basic or early abnormality in the plasma membrane of the muscle fiber. Neurology 1975, 25, 1111-1120. [CrossRef] [PubMed]

59. Allen, D.G.; Whitehead, N.P. Duchenne muscular dystrophy-what causes the increased membrane permeability in skeletal muscle? Int. J. Biochem. Cell Biol. 2011, 43, 290-294. [CrossRef]

60. Hutter, O.F. The membrane hypothesis of Duchenne muscular dystrophy: Quest for functional evidence. J. Inherit. Metab. Dis. 1992, 15, 565-577. [CrossRef]

61. Anderson, J.T.; Rogers, R.P.; Jarrett, H.W. Ca ${ }^{2+}$-calmodulin binds to the carboxyl-terminal domain of dystrophin. J. Biol. Chem. 1996, 271, 6605-6610. [CrossRef]

62. Allen, D.G.; Whitehead, N.P.; Froehner, S.C. Absence of Dystrophin Disrupts Skeletal Muscle Signaling: Roles of Ca ${ }^{2+}$, Reactive Oxygen Species, and Nitric Oxide in the Development of Muscular Dystrophy. Physiol. Rev. 2016, 96, 253-305. [CrossRef] [PubMed]

63. Murphy, S.; Zweyer, M.; Henry, M.; Meleady, P.; Mundegar, R.R.; Swandulla, D.; Ohlendieck, K. Proteomic analysis of the sarcolemma-enriched fraction from dystrophic mdx-4cv skeletal muscle. J. Proteom. 2019, 191, 212-227. [CrossRef] [PubMed]

64. Phillips, M.F.; Quinlivan, R. Calcium antagonists for Duchenne muscular dystrophy. Cochrane Database Syst. Rev. 2008, Cd004571. [CrossRef]

65. Friedrich, O.; von Wegner, F.; Chamberlain, J.S.; Fink, R.H.; Rohrbach, P. L-type Ca ${ }^{2+}$ channel function is linked to dystrophin expression in mammalian muscle. PLoS ONE 2008, 3, e1762. [CrossRef]

66. Hara, H.; Nolan, P.M.; Scott, M.O.; Bucan, M.; Wakayama, Y.; Fischbeck, K.H. Running endurance abnormality in mdx mice. Muscle Nerve 2002, 25, 207-211. [CrossRef] [PubMed]

67. Shoji, E.; Sakurai, H.; Nishino, T.; Nakahata, T.; Heike, T.; Awaya, T.; Fujii, N.; Manabe, Y.; Matsuo, M.; Sehara-Fujisawa, A. Early pathogenesis of Duchenne muscular dystrophy modelled in patient-derived human induced pluripotent stem cells. Sci. Rep. 2015, 5, 12831. [CrossRef]

68. Ullrich, N.D.; Fanchaouy, M.; Gusev, K.; Shirokova, N.; Niggli, E. Hypersensitivity of excitation-contraction coupling in dystrophic cardiomyocytes. Am. J. Physiol. Heart Circ. Physiol. 2009, 297, H1992-H2003. [CrossRef] 
69. Tanihata, J.; Nagata, T.; Ito, N.; Saito, T.; Nakamura, A.; Minamisawa, S.; Aoki, Y.; Ruegg, U.T.; Takeda, S. Truncated dystrophin ameliorates the dystrophic phenotype of $\mathrm{mdx}$ mice by reducing sarcolipin-mediated SERCA inhibition. Biochem. Biophys. Res. Commun. 2018, 505, 51-59. [CrossRef]

70. Landi, N.; Nassi, P.; Liguri, G.; Bobbi, S.; Sbrilli, C.; Marconi, G. Sarcoplasmic reticulum Ca ${ }^{2+}$-ATPase and acylphosphatase activities in muscle biopsies from patients with Duchenne muscular dystrophy. Clin. Chim. Acta Int. J. Clin. Chem. 1986, 158, 245-251. [CrossRef]

71. Gómez, J.; Neco, P.; DiFranco, M.; Vergara, J.L. Calcium release domains in mammalian skeletal muscle studied with two-photon imaging and spot detection techniques. J. Gen. Physiol. 2006, 127, 623-637. [CrossRef]

72. Badalamente, M.A.; Stracher, A. Delay of muscle degeneration and necrosis in mdx mice by calpain inhibition. Muscle Nerve 2000, 23, 106-111. [CrossRef]

73. Burr, A.R.; Molkentin, J.D. Genetic evidence in the mouse solidifies the calcium hypothesis of myofiber death in muscular dystrophy. Cell Death Differ. 2015, 22, 1402-1412. [CrossRef]

74. Onopiuk, M.; Brutkowski, W.; Wierzbicka, K.; Wojciechowska, S.; Szczepanowska, J.; Fronk, J.; Lochmuller, H.; Gorecki, D.C.; Zablocki, K. Mutation in dystrophin-encoding gene affects energy metabolism in mouse myoblasts. Biochem. Biophys. Res. Commun. 2009, 386, 463-466. [CrossRef] [PubMed]

75. Gosselin, M.R.F.; Mournetas, V.; Borczyk, M.; Bozycki, L.; Korostynski, M.; Robson, S.; Pinset, C.; Górecki, D.C. Loss of full-length dystrophin expression results in major cell-autonomous abnormalities in proliferating myoblasts. bioRxiv 2021. [CrossRef]

76. Gonzalez, J.P.; Kyrychenko, S.; Kyrychenko, V.; Schneider, J.S.; Granier, C.J.; Himelman, E.; Lahey, K.C.; Zhao, Q.; Yehia, G.; Tao, Y.X.; et al. Small Fractions of Muscular Dystrophy Embryonic Stem Cells Yield Severe Cardiac and Skeletal Muscle Defects in Adult Mouse Chimeras. Stem Cells 2017, 35, 597-610. [CrossRef]

77. Palladino, M.; Gatto, I.; Neri, V.; Straino, S.; Smith, R.C.; Silver, M.; Gaetani, E.; Marcantoni, M.; Giarretta, I.; Stigliano, E.; et al. Angiogenic impairment of the vascular endothelium: A novel mechanism and potential therapeutic target in muscular dystrophy. Arter. Thromb. Vasc. Biol. 2013, 33, 2867-2876. [CrossRef]

78. Dabiré, H.; Barthélémy, I.; Blanchard-Gutton, N.; Sambin, L.; Sampedrano, C.C.; Gouni, V.; Unterfinger, Y.; Aguilar, P.; Thibaud, J.L.; Ghaleh, B.; et al. Vascular endothelial dysfunction in Duchenne muscular dystrophy is restored by bradykinin through upregulation of eNOS and nNOS. Basic Res. Cardiol. 2012, 107, 240. [CrossRef]

79. Kodippili, K.; Thorne, P.K.; Laughlin, M.H.; Duan, D. Dystrophin deficiency impairs vascular structure and function in the canine model of Duchenne muscular dystrophy. J. Pathol. 2021, 254, 589-605. [CrossRef]

80. Tennyson, C.N.; Klamut, H.J.; Worton, R.G. The human dystrophin gene requires 16 hours to be transcribed and is cotranscriptionally spliced. Nat. Genet. 1995, 9, 184-190. [CrossRef]

81. Dumont, N.A.; Wang, Y.X.; von Maltzahn, J.; Pasut, A.; Bentzinger, C.F.; Brun, C.E.; Rudnicki, M.A. Dystrophin expression in muscle stem cells regulates their polarity and asymmetric division. Nat. Med. 2015, 21, 1455-1463. [CrossRef] [PubMed]

82. Neueder, A. RNA-Mediated Disease Mechanisms in Neurodegenerative Disorders. J. Mol. Biol. 2019, 431, 1780-1791. [CrossRef] [PubMed]

83. Kamieniarz-Gdula, K.; Proudfoot, N.J. Transcriptional Control by Premature Termination: A Forgotten Mechanism. Trends Genet. 2019, 35, 553-564. [CrossRef]

84. Williams, I.A.; Allen, D.G. Intracellular calcium handling in ventricular myocytes from mdx mice. Am. J. Physiol. Heart Circ. Physiol. 2007, 292, H846-H855. [CrossRef] [PubMed]

85. Kyrychenko, S.; Poláková, E.; Kang, C.; Pocsai, K.; Ullrich, N.D.; Niggli, E.; Shirokova, N. Hierarchical accumulation of RyR post-translational modifications drives disease progression in dystrophic cardiomyopathy. Cardiovasc. Res. 2013, 97, 666-675. [CrossRef] [PubMed]

86. Viola, H.M.; Adams, A.M.; Davies, S.M.K.; Fletcher, S.; Filipovska, A.; Hool, L.C. Impaired functional communication between the L-type calcium channel and mitochondria contributes to metabolic inhibition in the $m d x$ heart. Proc. Natl. Acad. Sci. USA 2014, 111, E2905-E2914. [CrossRef] [PubMed]

87. Podkalicka, P.; Mucha, O.; Dulak, J.; Loboda, A. Targeting angiogenesis in Duchenne muscular dystrophy. Cell. Mol. Life Sci. CMLS 2019, 76, 1507-1528. [CrossRef]

88. Khurana, T.S.; Prendergast, R.A.; Alameddine, H.S.; Tomé, F.M.; Fardeau, M.; Arahata, K.; Sugita, H.; Kunkel, L.M. Absence of extraocular muscle pathology in Duchenne's muscular dystrophy: Role for calcium homeostasis in extraocular muscle sparing. J. Exp. Med. 1995, 182, 467-475. [CrossRef]

89. Murphy, S.; Zweyer, M.; Henry, M.; Meleady, P.; Mundegar, R.R.; Swandulla, D.; Ohlendieck, K. Label-free mass spectrometric analysis reveals complex changes in the brain proteome from the $\mathrm{mdx}-4 \mathrm{cv}$ mouse model of Duchenne muscular dystrophy. Clin. Proteom. 2015, 12, 27. [CrossRef]

90. Aleman, V.; Osorio, B.; Chavez, O.; Rendon, A.; Mornet, D.; Martinez, D. Subcellular localization of Dp71 dystrophin isoforms in cultured hippocampal neurons and forebrain astrocytes. Histochem. Cell Biol. 2001, 115, 243-254. [CrossRef]

91. Blake, D.J.; Hawkes, R.; Benson, M.A.; Beesley, P.W. Different dystrophin-like complexes are expressed in neurons and glia. J. Cell Biol. 1999, 147, 645-658. [CrossRef] [PubMed]

92. Lidov, H.G.; Byers, T.J.; Kunkel, L.M. The distribution of dystrophin in the murine central nervous system: An immunocytochemical study. Neuroscience 1993, 54, 167-187. [CrossRef]

93. Sekiguchi, M. The role of dystrophin in the central nervous system: A mini review. Acta Myol. 2005, 24, 93-97. [PubMed] 
94. Souttou, S.; Benabdesselam, R.; Siqueiros-Marquez, L.; Sifi, M.; Deliba, M.; Vacca, O.; Charles-Messance, H.; Vaillend, C.; Rendon, A.; Guillonneau, X.; et al. Expression and localization of dystrophins and $\beta$-dystroglycan in the hypothalamic supraoptic nuclei of rat from birth to adulthood. Acta Histochem. 2019, 121, 218-226. [CrossRef] [PubMed]

95. Hopf, F.W.; Steinhardt, R.A. Regulation of intracellular free calcium in normal and dystrophic mouse cerebellar neurons. Brain Res. 1992, 578, 49-54. [CrossRef]

96. Vaillend, C.; Billard, J.M. Facilitated CA1 hippocampal synaptic plasticity in dystrophin-deficient mice: Role for GABAA receptors? Hippocampus 2002, 12, 713-717. [CrossRef] [PubMed]

97. Vaillend, C.; Billard, J.M.; Claudepierre, T.; Rendon, A.; Dutar, P.; Ungerer, A. Spatial discrimination learning and CA1 hippocampal synaptic plasticity in $\mathrm{mdx}$ and $\mathrm{mdx} 3 \mathrm{cv}$ mice lacking dystrophin gene products. Neuroscience 1998, 86, 53-66. [CrossRef]

98. Fritschy, J.M.; Schweizer, C.; Brunig, I.; Luscher, B. Pre- and post-synaptic mechanisms regulating the clustering of type A gamma-aminobutyric acid receptors (GABAA receptors). Biochem. Soc. Trans. 2003, 31, 889-892. [CrossRef]

99. Knuesel, I.; Zuellig, R.A.; Schaub, M.C.; Fritschy, J.M. Alterations in dystrophin and utrophin expression parallel the reorganization of GABAergic synapses in a mouse model of temporal lobe epilepsy. Eur. J. Neurosci. 2001, 13, 1113-1124. [CrossRef]

100. Sekiguchi, M.; Zushida, K.; Yoshida, M.; Maekawa, M.; Kamichi, S.; Yoshida, M.; Sahara, Y.; Yuasa, S.; Takeda, S.; Wada, K. A deficit of brain dystrophin impairs specific amygdala GABAergic transmission and enhances defensive behaviour in mice. Brain 2008, 132, 124-135. [CrossRef]

101. Sumita, K.; Sato, Y.; Iida, J.; Kawata, A.; Hamano, M.; Hirabayashi, S.; Ohno, K.; Peles, E.; Hata, Y. Synaptic scaffolding molecule (S-SCAM) membrane-associated guanylate kinase with inverted organization (MAGI)-2 is associated with cell adhesion molecules at inhibitory synapses in rat hippocampal neurons. J. Neurochem. 2007, 100, 154-166. [CrossRef] [PubMed]

102. Tuckett, E.; Gosetti, T.; Hayes, A.; Rybalka, E.; Verghese, E. Increased calcium in neurons in the cerebral cortex and cerebellum is not associated with cell loss in the mdx mouse model of Duchenne muscular dystrophy. Neuroreport 2015, 26, 785-790. [CrossRef] [PubMed]

103. Ruggieri, S.; Viggiano, L.; Annese, T.; Rubolino, C.; Gerbino, A.; De Zio, R.; Corsi, P.; Tamma, R.; Ribatti, D.; Errede, M.; et al. DP71 and SERCA2 alteration in human neurons of a Duchenne muscular dystrophy patient. Stem Cell Res. Ther. $2019,10,29$. [CrossRef] [PubMed]

104. Tsurumi, F.; Baba, S.; Yoshinaga, D.; Umeda, K.; Hirata, T.; Takita, J.; Heike, T. The intracellular Ca ${ }^{2+}$ concentration is elevated in cardiomyocytes differentiated from hiPSCs derived from a Duchenne muscular dystrophy patient. PLoS ONE 2019, 14, e0213768. [CrossRef] [PubMed]

105. Robin, G.; Berthier, C.; Allard, B. Sarcoplasmic reticulum $\mathrm{Ca}^{2+}$ permeation explored from the lumen side in mdx muscle fibers under voltage control. J. Gen. Physiol. 2012, 139, 209-218. [CrossRef] [PubMed]

106. Patel, A.M.; Wierda, K.; Thorrez, L.; van Putten, M.; De Smedt, J.; Ribeiro, L.; Tricot, T.; Gajjar, M.; Duelen, R.; Van Damme, P.; et al. Dystrophin deficiency leads to dysfunctional glutamate clearance in iPSC derived astrocytes. Transl. Psychiatry 2019, 9, 200. [CrossRef]

107. Del Tongo, C.; Carretta, D.; Fulgenzi, G.; Catini, C.; Minciacchi, D. Parvalbumin-positive GABAergic interneurons are increased in the dorsal hippocampus of the dystrophic mdx mouse. Acta Neuropathol. 2009, 118, 803-812. [CrossRef]

108. Krasowska, E.; Zabłocki, K.; Górecki, D.C.; Swinny, J.D. Aberrant location of inhibitory synaptic marker proteins in the hippocampus of dystrophin-deficient mice: Implications for cognitive impairment in duchenne muscular dystrophy. PLoS ONE 2014, 9, e108364. [CrossRef]

109. Chavas, J.; Forero, M.E.; Collin, T.; Llano, I.; Marty, A. Osmotic tension as a possible link between GABA(A) receptor activation and intracellular calcium elevation. Neuron 2004, 44, 701-713. [CrossRef]

110. Nico, B.; Frigeri, A.; Nicchia, G.P.; Corsi, P.; Ribatti, D.; Quondamatteo, F.; Herken, R.; Girolamo, F.; Marzullo, A.; Svelto, M.; et al. Severe alterations of endothelial and glial cells in the blood-brain barrier of dystrophic mdx mice. Glia 2003, 42, 235-251. [CrossRef]

111. Lien, C.F.; Mohanta, S.K.; Frontczak-Baniewicz, M.; Swinny, J.D.; Zablocka, B.; Gorecki, D.C. Absence of glial alpha-dystrobrevin causes abnormalities of the blood-brain barrier and progressive brain edema. J. Biol. Chem. 2012, 287, 41374-41385. [CrossRef]

112. Nico, B.; Tamma, R.; Annese, T.; Mangieri, D.; De Luca, A.; Corsi, P.; Benagiano, V.; Longo, V.; Crivellato, E.; Salmaggi, A.; et al. Glial dystrophin-associated proteins, laminin and agrin, are downregulated in the brain of mdx mouse. Lab. Investig. J. Tech. Methods Pathol. 2010, 90, 1645-1660. [CrossRef]

113. Duchen, M.R. Mitochondria and calcium: From cell signalling to cell death. J. Physiol. 2000, 529, 57-68. [CrossRef]

114. Balaban, R.S. The role of $\mathrm{Ca}^{2+}$ signaling in the coordination of mitochondrial ATP production with cardiac work. Biochim. Biophys. Acta 2009, 1787, 1334-1341. [CrossRef]

115. Berchtold, M.W.; Brinkmeier, H.; Müntener, M. Calcium ion in skeletal muscle: Its crucial role for muscle function, plasticity, and disease. Physiol. Rev. 2000, 80, 1215-1265. [CrossRef]

116. Halestrap, A.P. Calcium, mitochondria and reperfusion injury: A pore way to die. Biochem. Soc. Trans. 2006, 34, $232-237$. [CrossRef]

117. Zhang, S.S.; Zhou, S.; Crowley-McHattan, Z.J.; Wang, R.Y.; Li, J.P. A Review of the Role of Endo/Sarcoplasmic ReticulumMitochondria $\mathrm{Ca}^{2+}$ Transport in Diseases and Skeletal Muscle Function. Int. J. Environ. Res. Public Health 2021, $18,3874$. [CrossRef] [PubMed] 
118. Dubinin, M.V.; Talanov, E.Y.; Tenkov, K.S.; Starinets, V.S.; Mikheeva, I.B.; Belosludtsev, K.N. Transport of $\mathrm{Ca}^{2+}$ and Ca $^{2+}$-dependent permeability transition in heart mitochondria in the early stages of Duchenne muscular dystrophy. Biochim. Biophys. Acta Bioenerg. 2020, 1861, 148250. [CrossRef]

119. Kyrychenko, V.; Poláková, E.; Janíček, R.; Shirokova, N. Mitochondrial dysfunctions during progression of dystrophic cardiomyopathy. Cell Calcium 2015, 58, 186-195. [CrossRef] [PubMed]

120. Charge, S.B.; Rudnicki, M.A. Cellular and molecular regulation of muscle regeneration. Physiol. Rev. 2004, 84, 209-238. [CrossRef] [PubMed]

121. Hussein, M.R.; Abu-Dief, E.E.; Kamel, N.F.; Mostafa, M.G. Steroid therapy is associated with decreased numbers of dendritic cells and fibroblasts, and increased numbers of satellite cells, in the dystrophic skeletal muscle. J. Clin. Pathol. 2010, 63, 805-813. [CrossRef] [PubMed]

122. Pellegrini, C.; Zulian, A.; Gualandi, F.; Manzati, E.; Merlini, L.; Michelini, M.E.; Benassi, L.; Marmiroli, S.; Ferlini, A.; Sabatelli, P.; et al. Melanocytes-A novel tool to study mitochondrial dysfunction in Duchenne muscular dystrophy. J. Cell. Physiol. 2013, 228, 1323-1331. [CrossRef] [PubMed]

123. Law, M.L.; Cohen, H.; Martin, A.A.; Angulski, A.B.B.; Metzger, J.M. Dysregulation of Calcium Handling in Duchenne Muscular Dystrophy-Associated Dilated Cardiomyopathy: Mechanisms and Experimental Therapeutic Strategies. J. Clin. Med. 2020, 9, 520. [CrossRef]

124. Meyers, T.A.; Townsend, D. Cardiac Pathophysiology and the Future of Cardiac Therapies in Duchenne Muscular Dystrophy. Int. J. Mol. Sci. 2019, 20, 4098. [CrossRef] [PubMed]

125. Mareedu, S.; Million, E.D.; Duan, D.; Babu, G.J. Abnormal Calcium Handling in Duchenne Muscular Dystrophy: Mechanisms and Potential Therapies. Front. Physiol. 2021, 12, 647010. [CrossRef]

126. Angebault, C.; Panel, M.; Lacôte, M.; Rieusset, J.; Lacampagne, A.; Fauconnier, J. Metformin Reverses the Enhanced Myocardial SR/ER-Mitochondria Interaction and Impaired Complex I-Driven Respiration in Dystrophin-Deficient Mice. Front. Cell Dev. Biol. 2020, 8, 609493. [CrossRef]

127. Dong, X.; Hui, T.; Chen, J.; Yu, Z.; Ren, D.; Zou, S.; Wang, S.; Fei, E.; Jiao, H.; Lai, X. Metformin Increases Sarcolemma Integrity and Ameliorates Neuromuscular Deficits in a Murine Model of Duchenne Muscular Dystrophy. Front. Physiol. 2021, 12, 642908. [CrossRef]

128. Ljubicic, V.; Jasmin, B.J. Metformin increases peroxisome proliferator-activated receptor $\gamma$ Co-activator- $1 \alpha$ and utrophin a expression in dystrophic skeletal muscle. Muscle Nerve 2015, 52, 139-142. [CrossRef] [PubMed]

129. Dubinin, M.V.; Talanov, E.Y.; Tenkov, K.S.; Starinets, V.S.; Belosludtseva, N.V.; Belosludtsev, K.N. The Effect of Deflazacort Treatment on the Functioning of Skeletal Muscle Mitochondria in Duchenne Muscular Dystrophy. Int. J. Mol. Sci. 2020, $21,8763$. [CrossRef]

130. Yasuda, S.; Townsend, D.; Michele, D.E.; Favre, E.G.; Day, S.M.; Metzger, J.M. Dystrophic heart failure blocked by membrane sealant poloxamer. Nature 2005, 436, 1025-1029. [CrossRef]

131. Terry, R.L.; Kaneb, H.M.; Wells, D.J. Poloxamer 188 has a deleterious effect on dystrophic skeletal muscle function. PLoS ONE 2014, 9, e91221, Erratum in 2015, 10, e0119252. [CrossRef]

132. Quinlan, J.G.; Wong, B.L.; Niemeier, R.T.; McCullough, A.S.; Levin, L.; Emanuele, M. Poloxamer 188 failed to prevent exerciseinduced membrane breakdown in mdx skeletal muscle fibers. Neuromuscul. Disord. 2006, 16, 855-864. [CrossRef]

133. Vaillend, C.; Perronnet, C.; Ros, C.; Gruszczynski, C.; Goyenvalle, A.; Laroche, S.; Danos, O.; Garcia, L.; Peltekian, E. Rescue of a dystrophin-like protein by exon skipping in vivo restores GABAA-receptor clustering in the hippocampus of the mdx mouse. Mol. Ther. J. Am. Soc. Gene Ther. 2010, 18, 1683-1688. [CrossRef]

134. Young, C.N.; Sinadinos, A.; Lefebvre, A.; Chan, P.; Arkle, S.; Vaudry, D.; Gorecki, D.C. A novel mechanism of autophagic cell death in dystrophic muscle regulated by P2RX7 receptor large-pore formation and HSP90. Autophagy 2015, 11, 113-130. [CrossRef]

135. Browne, S.E. When too much ATP is a bad thing: A pivotal role for P2X(7) receptors in motor neuron degeneration. J. Neurochem. 2013, 126, 301-304. [CrossRef]

136. Gazzerro, E.; Baldassari, S.; Assereto, S.; Fruscione, F.; Pistorio, A.; Panicucci, C.; Volpi, S.; Perruzza, L.; Fiorillo, C.; Minetti, C.; et al. Enhancement of Muscle T Regulatory Cells and Improvement of Muscular Dystrophic Process in mdx Mice by Blockade of Extracellular ATP/P2X Axis. Am. J. Pathol. 2015, 185, 3349-3360. [CrossRef]

137. Al-Khalidi, R.; Panicucci, C.; Cox, P.; Chira, N.; Róg, J.; Young, C.N.J.; McGeehan, R.E.; Ambati, K.; Ambati, J.; Zabłocki, K.; et al. Zidovudine ameliorates pathology in the mouse model of Duchenne muscular dystrophy via P2RX7 purinoceptor antagonism. Acta Neuropathol. Commun. 2018, 6, 27. [CrossRef]

138. Sinadinos, A.; Young, C.N.; Al-Khalidi, R.; Teti, A.; Kalinski, P.; Mohamad, S.; Floriot, L.; Henry, T.; Tozzi, G.; Jiang, T.; et al. P2RX7 purinoceptor: A therapeutic target for ameliorating the symptoms of duchenne muscular dystrophy. PLoS Med. 2015, 12, e1001888. [CrossRef] [PubMed]

139. Young, C.N.; Brutkowski, W.; Lien, C.F.; Arkle, S.; Lochmuller, H.; Zablocki, K.; Gorecki, D.C. P2X7 purinoceptor alterations in dystrophic mdx mouse muscles: Relationship to pathology and potential target for treatment. J. Cell. Mol. Med. 2012, 16, 1026-1037. [CrossRef] [PubMed]

140. Arbeloa, J.; Perez-Samartin, A.; Gottlieb, M.; Matute, C. P2X7 receptor blockade prevents ATP excitotoxicity in neurons and reduces brain damage after ischemia. Neurobiol. Dis. 2012, 45, 954-961. [CrossRef] [PubMed] 
141. Górecki, D.C. P2X7 purinoceptor as a therapeutic target in muscular dystrophies. Curr. Opin. Pharmacol. 2019, 47, 40-45. [CrossRef]

142. Dabertrand, F.; Mironneau, J.; Henaff, M.; Macrez, N.; Morel, J.L. Comparison between gentamycin and exon skipping treatments to restore ryanodine receptor subtype 2 functions in $\mathrm{mdx}$ mouse duodenum myocytes. Eur. J. Pharm. 2010, 628, 36-41. [CrossRef] [PubMed]

143. Takeda, S.; Clemens, P.R.; Hoffman, E.P. Exon-Skipping in Duchenne Muscular Dystrophy. J. Neuromuscul. Dis. 2021, 1-16. [CrossRef] [PubMed]

144. Capitanio, D.; Moriggi, M.; Torretta, E.; Barbacini, P.; De Palma, S.; Viganò, A.; Lochmüller, H.; Muntoni, F.; Ferlini, A.; Mora, M.; et al. Comparative proteomic analyses of Duchenne muscular dystrophy and Becker muscular dystrophy muscles: Changes contributing to preserve muscle function in Becker muscular dystrophy patients. J. Cachexia Sarcopenia Muscle 2020, 11, 547-563. [CrossRef]

145. Sato, M.; Shiba, N.; Miyazaki, D.; Shiba, Y.; Echigoya, Y.; Yokota, T.; Takizawa, H.; Aoki, Y.; Takeda, S.; Nakamura, A. Amelioration of intracellular $\mathrm{Ca}^{2+}$ regulation by exon-45 skipping in Duchenne muscular dystrophy-induced pluripotent stem cell-derived cardiomyocytes. Biochem. Biophys. Res. Commun. 2019, 520, 179-185. [CrossRef] [PubMed]

146. Vulin, A.; Barthélémy, I.; Goyenvalle, A.; Thibaud, J.L.; Beley, C.; Griffith, G.; Benchaouir, R.; le Hir, M.; Unterfinger, Y.; Lorain, S.; et al. Muscle function recovery in golden retriever muscular dystrophy after AAV1-U7 exon skipping. Mol. Ther. J. Am. Soc. Gene Ther. 2012, 20, 2120-2133. [CrossRef] [PubMed] 